NBER WORKING PAPER SERIES

\title{
EVALUATING THE IMPACT OF THE D.C. TUITION ASSISTANCE GRANT PROGRAM
}

\author{
Thomas Kane \\ Working Paper 10658 \\ http://www.nber.org/papers/w10658 \\ NATIONAL BUREAU OF ECONOMIC RESEARCH \\ 1050 Massachusetts Avenue \\ Cambridge, MA 02138 \\ August 2004
}

I gratefully acknowledge support from the Ford Foundation and the Atlantic Philanthropies. Laurent Ross, the original director of the D.C. Tuition Assistance Grant (D.C. TAG) program, suggested this project in the Spring of 2000. Leonard Proctor, the director from 2002 to 2004 and Rehva Jones on his staff provided much helpful data. Daniel Madzelan at the U.S. Department of Education provided data on FAFSA applicants and Pell Grant recipients from Maryland, Virginia and D.C. Douglas O. Staiger, Jeffrey Grogger, Jens Ludwig, Enrico Moretti, Argelia Rodriguez, Sarah Turner and Wayne Upshaw offered a number of helpful suggestions. Jennifer Kron, Rehva Jones and Laurent Ross offered comments on an earlier draft. Virginia Nguyen provided research assistance. The views expressed herein are those of the author(s) and not necessarily those of the National Bureau of Economic Research.

(C2004 by Thomas Kane. All rights reserved. Short sections of text, not to exceed two paragraphs, may be quoted without explicit permission provided that full credit, including (C) notice, is given to the source. 
Evaluating the Impact of the D.C. Tuition Assistance Program

Thomas Kane

NBER Working Paper No. 10658

August 2004

JEL No. I2

\section{$\underline{\text { ABSTRACT }}$}

In the Fall of 2000, the D.C. Tuition Assistance Grant program dramatically changed the menu of college prices offered to residents of the District of Columbia. The program allowed residents of D.C. to attend public institutions in Maryland and Virginia and pay the same tuition as residents of those states. Between 1998 and 2000 (the first year of the program), the number of D.C. residents attending public institutions in Virginia and Maryland more than doubled. When public institutions in other states were included in subsequent years, the number of D.C. residents attending these institutions also nearly doubled. The increases were largest at non-selective public 4-year institutions in the mid-Atlantic states, particular predominantly black public institutions in Maryland and Virginia. College entry rates by D.C. residents also seemed to increase. The number of first-time federal financial aid applicants, the number of first-year college students receiving Pell Grants and the number of district residents reported as freshmen by colleges and universities nationwide all increased by 15 percent or more, while the number of graduates from D.C. public high schools remained flat.

Thomas Kane

School of Public Policy and Social Research

UCLA, Box 951656

Los Angeles, CA 90095-1656

and NBER

tomkane@ucla.edu 


\section{Introduction}

The distributional implications of state subsidies to public higher education, and the policy of keeping low tuition for all students regardless of need, have been the subject of intense debate for decades. ${ }^{1}$ However, because such subsidies are an established feature of the U.S. higher education landscape, it is difficult as an empirical matter to identify their impact on enrollment decisions.

In the fall of 2000 , the U.S. Congress created an opportunity to shed new light on this old debate, by dramatically changing the menu of college prices offered to residents of the District of Columbia. Prior to the fall of 2000, residents of the district were offered one subsidized public institution, the University of the District of Columbia (UDC), an open-admissions institution that operates much like a community college. With UDC as their only subsidized public option, two-thirds of district residents (64 percent) enrolled at institutions outside of the district. ${ }^{2}$ (Elsewhere in the U.S., only 15 percent of college entrants elsewhere attended schools outside of their state.) Moreover, roughly two-thirds of district residents enrolled in private institutions prior to 2000-- roughly twice the rate of students elsewhere in the U.S.. ${ }^{3}$

As a result, residents of the District of Columbia typically paid much more to attend college than residents of other states prior to 2000. During the 1999-00 school year, dependent undergraduates from the District of Columbia paid $\$ 7,890$ per year in tuition minus all grant aid

${ }^{1}$ See, for example, Hartman (1971), Hansen and Weisbrod (1969 and 1971) and Pechman (1970 and 1971). The debate is summarized in Kane (1999).

${ }^{2}$ Digest of Education Statistics, 2002, Table 203.

${ }^{3}$ Author's tabulation of proportion of first-time freshmen, recent high school graduates attending public institutions in fall of 1998. 
(including means-tested federal grants). ${ }^{4}$ This was more than twice the national average for dependent students (which was $\$ 3,215$ ), even though the proportion of families below the poverty line in the district is among the highest in the nation.

Beginning in the fall of 2000, district residents became eligible for a D.C. Tuition Assistance Grant (D.C. TAG) to pay the difference between in-state and out-of-state tuition at public institutions in other states (up to $\$ 10,000$ ). Despite the prominent example of the University of Virginia (where the difference in tuition for residents and non-residents was $\$ 15,210$ in 2002), the $\$ 10,000$ maximum was sufficient to cover the price difference between in state and out-of-state residents at most public institutions: out of 606 public 4-year institutions nationally reporting tuition for the fall 2002-03 school year, the difference between resident and non-resident tuition exceeded the $\$ 10,000$ maximum in only $69 .^{5}$

The D.C. TAG program suddenly provided essentially the same menu of subsidized options offered to residents of other states (in fact, offering the best of options across all the states). My goal in this paper is to report on the apparent impacts on students' enrollment decisions.

${ }^{4}$ Author's tabulation of the National Postsecondary Student Aid Survey, 1999-2000. Data reported in Appendix Table 1.

${ }^{5}$ Since that time, large increase in public tuition levels, has increased the number of schools where the difference between in-state and out-of-state tuition exceeds $\$ 10,000$. 


\section{Description of D.C. Tuition Assistance Grant Program}

The legislative history of the District of Columbia College Access Act was remarkably brief, its introduction and swift passage fitting neatly between the end of one admission cycle and the beginning of the next. Co-sponsored by Rep. Eleanor Holmes Norton of D.C., Rep. Thomas Davis of Virginia and Rep. Constance Morella of Maryland (and eight others), the legislation was introduced in the U.S. House of Representatives in March of 1999 (H.R. 974), as the admission season for the fall of 1999 would have been closing. The bill was passed by the House in May 1999 and was passed by the Senate in October of 1999. The legislation was signed by President Clinton on November 12, 1999 (P.L. 106-98), just as the new admission season was heating up.

In addition to providing grants for students at public institutions, the law provided for smaller grants for those choosing selected private institutions in D.C., Maryland or Virginia. D.C. residents attending private non-profit institutions in the D.C. metropolitan area and private non-profit historically black institutions Maryland and Virginia received $\$ 2500 .^{6}$ (Students attending public historically black institutions qualified for the full grants.) Students attending private, for-profit institutions- such as those that provide certificates for occupational training-were not eligible for the D.C. TAG program.

${ }^{6}$ Those receiving the $\$ 10,000$ grants to attend public institutions face a lifetime cap of $\$ 50,000$. There is a $\$ 12,500$ cap on the grants for those attending private institutions. Originally, the qualifying private institutions were American University, Capitol College, Catholic University, Columbia Union College, the Corcoran School of Art, Gallaudet University, George Washington University, Georgetown University, Hampton University, Howard University, Maryland College of Art and Design, Marymount University, Saint Paul's College, Southeastern University, Trinity College, Virginia Union University, Washington Adventist Hospital School of Radiography and Washington Bible College. 
Originally, the program was limited to D.C. residents without a prior bachelor's degree, who had graduated from high school in 1998 or later. ${ }^{7}$ Students had to be attending college at least half-time. Students who had already started college were eligible, as long as they met the residency requirement and had graduated since 1998. The program was not limited to those graduating from D.C. public schools; those attending private schools or public schools outside the district were also eligible, as long as they met the residency requirement.

To meet the residency requirement, applicants were required to provide D.C. tax returns and other documentation, such as drivers' licenses and utility bills. ${ }^{8}$ For dependent students (those who had been claimed as a dependent on a parent's tax return), the parent needed to prove residency; for independent students, residency depended upon the student's residence.

The program has been expanded twice. Originally, the program was limited to public institutions in Virginia and Maryland, but the law allowed the Mayor to expand the program to public institutions in other states. In May of 2000, Mayor Anthony Williams took that step, and announced that the grants could be used at public institutions outside of Virginia and Maryland. Having been announced in May, however, the expansion came too late to have much impact on enrollment decisions for the Fall of 2000. Students are likely to have been even more confused when, in the Fall of 2000, four large public institutions- the University of Michigan, the University of Florida, the University of California and the State University of New Yorkrefused to sign the participation agreement, complaining that the reporting requirements were too

\footnotetext{
${ }^{7}$ Students were also ineligible if they had defaulted on a prior student loan or had failed to register for selective service (if they were male). Revenue.

${ }^{8}$ The program relied primarily on tax returns certified by the D.C. Office of Tax and
} 
burdensome. An agreement was eventually reached with these institutions in December 2000, just in time for the new admission season. (I will report evidence that the enrollment impacts at public institutions outside of Maryland and Virginia did not occur until after Fall of 2000.)

In April of 2002 (for the students entering in the fall of 2003), the program was changed again in several ways. Most importantly, all private, historically black institutions-- not just those in Maryland and Virginia- were made eligible for the $\$ 2500$ awards. ${ }^{9}$

\section{Literature Review}

An extensive literature has attempted to measure the impact of various types of tuition and financial aid policies on college-going. Much of that work has focused on the decision to enroll in college (often referred to as college access). Others have studied the impact of college prices on the proportion of students attending a specific institution or type of institution (often referred to as college choice). In their review of the literature on student responsiveness to changes in college cost, Leslie and Brinkman (1988) report a consensus estimate that a $\$ 1000$ change in college costs (2001 dollars) is associated with a 4 percentage point difference in college enrollment rates. A number have papers have used between-state differences in state tuition policy and essentially compare the college entry rates of otherwise similar youth in high and low-tuition states. ${ }^{10}$ The empirical strategy in this literature typically assumes that the

\footnotetext{
${ }^{9}$ In addition, those who had graduated before 1998 were made eligible, as long as they could show that they were enrolled in a D.C. TAG eligible institution in 2002 and could provide evidence of D.C. tax returns going back five years. Third, D.C. residents who were not citizens or permanent residents of the United States were made ineligible.

${ }^{10}$ See, for example, Heckman and Cameron (1998), Kane (1994), Kane (1999), Card and Lemieux (2000).
} 
relevant price for marginal students is the tuition at public institutions in their state and evaluates the effect of tuition and college-going by comparing college-going rates in high and low-tuition states. Such studies also assume that the supply of college slots is perfectly elastic: given a change in price, it is solely student demand which determines enrollment and not the supply of college slots.

An important weakness of these studies is that they rely on relatively fixed differences in tuition levels between states. For instance, California has been a relatively low-tuition state for the past forty years. California has also built a number of community colleges around the state. One may be attributing to tuition policy the effect of these other policy differences. Kane (1994) and Card and Lemieux (2000) include state fixed effects in an analysis using Current Population Survey data and find that the effect of public tuition levels is often not statistically significant. Kane(1994) finds a negative and statistically significant effect of tuition on African American youth after including state fixed effects, but the coefficient on tuition is no longer significant for whites with the inclusion of state fixed effects. Card and Lemieux (2000) report small (1 to 2 percentage point difference in college enrollment per $\$ 1000$ difference in tuition) and occasionally statistically insignificant effects of tuition on college going.

Susan Dynarski has estimated the impact of two important policy changes. One study focused on the impact of the cessation of tuition benefits for Social Security survivors and the other evaluated the effect of the Hope Scholarship program in Georgia. Dynarski (2003) found that after the discontinuation of the Social Security Student Benefit program, college entry by students with deceased parents declined dramatically, by 19 to 26 percentage points relative to other youth. To convert this estimate to a similar scale reported above, Dynarski calculated 
that the value of the benefit program had been roughly $\$ 6700$ (2001 dollars). This implies an impact of 3 to 4 percentage points per thousand dollar change in price.

In a second paper, Dynarski (studied enrollment rates for youth in Georgia relative to other southern states, before and after the Hope Scholarship program was initiated in that state. She estimates that the program increased college enrollment rates of 18 to 19 -year-olds by 7.0 to 7.9 percentage points. Given the value of the Hope Scholarship, this estimate converts to an estimate of 2 to 3 percentage points per $\$ 1000$ difference in cost.

In both of the articles by Dynarski, the source of variation in price is plausibly exogenous. However, in the analysis of tuition benefits for Social Security Survivors, it is difficult to know whether the responsiveness of such a narrow subgroup-- youth with deceased parents-- can be generalized to other groups. Moreover, the estimate is based upon an exceedingly small sample of 107 children of deceased parents before the change in policy and 49 after the change. In the case of the Hope Scholarship program in Georgia, one must presume that the impact estimates reflect some combination of supply and demand parameters: it is probably not plausible that the supply of college slots was perfectly elastic, since the program was affecting many of the residents of the same state.

Others have focused on the effect of price on choice of college. Manski and Wise (1983) found large effects of price relative to family income on choice of college. More recently, Wilbert van der Klaauw (1997) exploited discontinuities in the formula determining fellowship offers at a major eastern university to identify the effect of such offers on the decisions of students to attend that institution. His estimates suggest that each $\$ 1000$ in aid (2001 dollars) raises the likelihood of attending the university by 3-4 percentage points. A recent paper by 
Linsenmeier, Rosen and Rouse (2001) also evaluates the impact of one institution's decision to shift its financial aid to low-income students from loans to grants. They find no statistically significant impact on low-income youth in the aggregate, but do find marginally significant results for low-income minorities.

A recent paper by Abraham and Clark (2003) studied the impact of the D.C. Tuition Assistance Grant program on student application decisions and aggregate enrollment impacts in the first year of the program. Using data on SAT takers in D.C. and a comparison set of cities, they study changes in the proportion of D.C. residents having SAT scores sent to institutions outside D.C.. Beginning with high school students taking the SAT 1999-2000, relative to the comparison group, they report a 9 percentage point rise in the proportion of D.C. residents sending their scores to a public institution in Maryland or Virginia and a 6 percentage point increase the proportion sending their schools to public institutions in any state. They find an additional 6 percentage point rise in both figures relative to the comparison group in the 20002001 school year.

They also reported larger impacts for D.C. residents attending private high schools than for those attending D.C. public schools: relative to the comparison group, the proportion of D.C. residents sending scores to a public university nationwide rose by 21 points for private school students between 1999 and 2001, compared to 9 points for public school students. Using a similar technique, the rise relative to comparison students was also larger for white students in D.C. (23 points) than for black students (10 points).

However, program impacts on application decisions may be very different from impacts on enrollment decisions. Submitting an application is similar to purchasing an option. With the 
availability of the D.C. TAG grants, the chance of admission at a flagship public institution-such as the University of Virginia, University of Maryland, University of North Carolina or University of California-- became an increasingly valuable, but far-from-certain prospect for many D.C. residents. The fact that private school students and white youth were more likely to purchase that option does not necessarily mean that their enrollment decisions were more likely to be affected.

Abraham and Clark do present data on the aggregate enrollment growth for D.C. residents between 1998 and 2000 (using the same data I describe below). They report large increases in D.C. freshmen enrollment at public institutions in Maryland and Virginia between 1998 and 2000. (Similar figures were reported in Kane (2003).) However, they do not analyze the relationship between changes in enrollment and changes in effective prices at the institutional level. Moreover, they do not study the effect of subsequent expansions of the program. In this paper, I will analyze enrollment growth at the institution level, and for different types of institutions. In addition, I will examine enrollment data from 2002, and exploit the staggered timing of the implementation of the program between 1998 and 2002, when Maryland and Virginia public institutions and private HBCU's were first eligible and when public institutions and private HBCU's outside Maryland and Virginia were added to the program. Finally, I will provide data on the distribution of D.C. TAG benefits across different neighborhoods in the city, as well as study the impact on college choices for a sample of financial aid applicants.

\section{Data}

I use three sources of data in this analysis. First, I use data on state of residence for first- 
time freshmen from the Integrated Postsecondary Education Data System (IPEDS) from fall 1994 through 2002. Institutions were asked to report the total number of first-time freshmen by their state of residence prior to entry, as well as the subset of freshmen from each state who had graduated from high school in the previous 12 months. ${ }^{11}$

Second, I obtained data from the U.S. Department of Education on all of those submitting federal financial aid applications from D.C., Maryland and Virginia in the 1998-99 through 2001-02 award cycle. The federal financial aid form allows students to list the codes for up to 6 institutions to which they want their financial aid data to be sent. I use those data to study the change in the likelihood that a student would list a public institution on the form. Like Abraham and Clark (2003), I am able to study the change in the likelihood of listing a public institution among D.C. residents before and after 2000, relative to Maryland and Virginia residents. Moreover, for the subset of financial aid applicants receiving Pell Grants, I was able to identify the institution attended. Since private for-profit institutions participate in the federal student aid programs, the FAFSA data offer more reliable measures of proprietary school enrollment before and after the D.C. TAG program.

Finally, working with data from the D.C. Tuition Assistance Grant Program office, I identified the location of D.C. TAG grant recipients in D.C. by census tract and block group. I report evidence on the characteristics of the D.C. neighborhoods from which the D.C. TAG recipients were drawn, as well as the high schools they attended.

${ }^{11}$ At institutions- such as the University of the District of Columbia-- which enroll a large number of older students, there can be a large difference between the two series. 


\section{Impacts on Enrollment of Freshmen from D.C.}

I begin by analyzing the percentage changes in enrollment of D.C. residents at various institutions associated with changes in the prices faced by D.C. resident. If all residents have the same preferences as the representative consumer, the resulting coefficient on the price change has a natural interpretation as a parameter from a conditional logit specification.

Using the conditional logit specification (McFadden (1974)), suppose that the utility the representative person gains from choosing the ith school out of $\mathrm{m}$ choices is

$U_{i t}=\beta T_{i t}+\delta_{i}+\varepsilon_{i t}$, where $\mathrm{T}_{\mathrm{it}}$ is the tuition at the school and $\delta_{\mathrm{i}}$ represents college characteristics that are fixed in the short-term (such as the quality of the faculty) and $\varepsilon_{\mathrm{it}}$ represents unobserved variation in tastes and school attributes. If the residuals, $\varepsilon_{\mathrm{it}, \text { are }}$ a independently and identically distributed with the type I extreme-value distribution, then it can be shown that the probability that the representative consumer makes the ith choice can be written as below:

$$
P\left(Y_{i t}=1\right)=\frac{e^{T_{i t} \beta+\delta_{i}}}{\sum_{j=1}^{m} e^{T_{j t} \beta+\delta_{j}}}=p_{i t}
$$

The change over time in the log ratio of probability of choice i relative to some base choice o, can then be re-written as below: 


$$
\begin{aligned}
& \ln \left(\frac{p_{i 1}}{p_{o 1}}\right)-\ln \left(\frac{p_{i 0}}{p_{o 0}}\right)=\left(\left(T_{i 1}-T_{i 0}\right)-\left(T_{o 1}-T_{o 0}\right)\right) \beta \\
& \ln \left(n_{i 1}\right)-\ln \left(n_{i 0}\right)=\alpha+\left(\left(T_{i 1}-T_{i 0}\right)\right) \beta \\
& \text { where } \alpha=-\left(\ln \left(n_{o 1}\right)-\ln \left(n_{o 0}\right)\right)+\left(\left(T_{o 1}-T_{o 0}\right)\right) \beta, \text { a constant. }
\end{aligned}
$$

The last expression above describes a regression of the change in log enrollment of D.C. residents on a constant and the change in tuition charges faced by D.C. residents. Although tuition is the only school characteristic used in the model, taking differences over time accounts for other more difficult-to-measure, but fixed, institutional characteristics. In 1998, half of all D.C. freshmen attending an institution outside D.C. attended schools where they made up less than 1 percent (.8 percent) of the freshmen at the school. The maximum representation of D.C. residents in 1998 was at the Maryland College of Art and Design where they made up 12 percent of the student body. Given that D.C. residents accounted for a small share of students, it seems reasonable to assume that even a large change in attendance by D.C. students was unlikely to lead to important effects on total enrollments or institutional environments.

Table 1 reports the tuition paid by D.C. residents (in 2002 dollars), net of D.C. TAG grants, at different types of institutions for 1998 through 2002. (In calculating these means, each institution's tuition was weighted by the number of freshmen D.C. residents attending the institution in Fall of 1998, before the change in policy.) The first two rows describe categories of institutions whose prices were not directly affected by the change in policy- the University of 
the District of Columbia (UDC) and private, non-profit institutions outside of the D.C.

metropolitan area that were not historically black institutions. Tuition for D.C. residents at UDC actually fell in real value between 1998 and 2002 , from $\$ 2218$ to $\$ 2070$, while prices rose by about $\$ 2000$ at the private institutions outside D.C. over the period.

The next category of institutions, public 2-year and 4-year colleges outside D.C., were most directly affected by the establishment of the D.C. TAG program. The price of a public four-year institution in Maryland or Virginia fell by $\$ 6,212$ relative to the price at UDC between 1998 and 2000. Then between 2000 and 2002, the price of public 4-year institutions in the remainder of the country fell by $\$ 5,573$ relative to UDC. The staggered timing of the tuition changes- first at institutions in Maryland and Virginia and then at public institutions elsewherewill be helpful in identifying the impact of the program.

The timing and magnitude of the price changes also varied among private historically black institutions and private colleges in the D.C. area. The policy first affected only the private institutions in the D.C. area and private HBCU's in Maryland and Virginia. The prices at these institutions fell by $\$ 1,734$ and $\$ 2,510$ respectively relative to the price of UDC. Then, between 2000 and 2002, private HBCU's outside D.C. became eligible for the benefits and their prices also declined, by $\$ 1749$ relative to UDC.

The last two columns of Table 1 report the changes in absolute numbers of D.C. residents attending each category of school between 1998 and 2000. Between 1998 and 2000, the number of D.C. residents enrolling as first-time freshmen at public 4-year institutions in Maryland and Virginia more than doubled from 146 to 398 . The 252 additional students represented a 176 percent increase. However, the 15 student decline at the University of District of Columbia was 
small both in absolute and relative turns.

Rather, the big declines were at public institutions outside of Maryland and Virginia and at private colleges and HBCU's in D.C., Maryland and Virginia. Recall from Table 1, before the change in policy, the price of public 4-year colleges in Maryland and Virginia was similar on average to the price of a private historically black college- $\$ 10,783$ versus $\$ 10,373$. However, between 1998 and 2000, the price of a public 4-year college fell to almost half the price of a private HBCU- $\$ 4515$ versus $\$ 7807$. Rather than being UDC, the marginal institution for many of those newly entering at public 4-year institutions in Maryland or Virginia seems to have been a private college in D.C. or a public 4-year institution in other states. Between 2000 and 2002, when public institutions outside Maryland or Virginia were added to the list of eligible institutions, they also witnessed a large increase in the number of D.C. freshmen attending, rising by 252 students after falling by 53 students between 1998 and 2000 .

Table 2 reports the results of regressing log enrollment of D.C. residents on tuition for D.C. residents, time dummies and institutional fixed effects. To exploit the extra identification offered by the staggered implementation of the program for MD and VA public institutions in fall 2000 and subsequent expansion to institutions elsewhere, I first focus on the two firstdifferences- 1998 to 2000 and 2000 to 2002 - before pooling the three years. I also report the results separately for the two different freshmen enrollment series- total first-time freshmen from D.C. and the subset of freshmen from D.C. who had graduated from high school in the previous 12 months.

The top two panels report the results using any institution with 1 or more D.C. resident enrolled. Between 1998 and 2000, each $\$ 1000$ relative price decrease was associated with an 8 
percent increase in D.C. freshmen enrollment and a 10 percent increase in freshmen enrollment of recent high school graduates from D.C.. Between 2000 and 2002, when a different set of institutions faced the change in relative price, each $\$ 1000$ relative price change was associated with a 5 and 6 percentage point increase in enrollment. (The somewhat smaller impact of the latter change may have been due to the fact that D.C. residents were less likely to attend institutions far from D.C., even with the price change.) When pooling the three years, the results are again in the range of 5 and 6 percent increase in enrollment for every $\$ 1000$ decline in price for D.C. residents.

The bottom two panels of Table 2 limit the sample to institutions with 10 or more D.C. residents enrolled. The results are intended as a robustness check, since small absolute changes at institutions with small enrollments would represent large changes in log terms. The results are quite similar for the 1998 to 2000 period. For the period 2000 to 2002, the estimated impacts are actually larger when limiting the sample to institutions with larger enrollments (11 percent versus 5 percent and 9 percent versus 6 percent). Many of the institutions affected by the 2000 to 2002 policy change would have been distant public institutions and private HBCU's with smaller absolute numbers of D.C. residents attending.

Table 3 reports the results for various subsets of institutions, using the change in the log of the number of recent high school graduates from D.C. enrolled as the dependent variable. The top left panel limits the sample to institutions in D.C., Virginia, Pennsylvania, Maryland, North Carolina, New York, Georgia and Delaware. (In the order listed, institutions in these states enroll the largest shares of D.C. residents, together accounting for 76 percent of D.C. resident enrollment in 1998.) The top right panel reports the results for institutions in the 
remaining states. In the period 1998 to 2000, the standard error is quite large on the change in tuition in the states not nearby D.C., reflecting the fact that the D.C. TAG policy change did not affect those institutions. (There was still some natural variation in tuition prices due to differences in tuition policies, but apparently not enough to identify an effect.) Between 2000 and 2002, when the D.C. TAG program was expanded to include public institutions in these other states, the impact on D.C. resident enrollment of a tuition increase was negative and statistically significant in both sets of states, but the point estimate was slightly larger in the states where D.C. residents typically attend (although not statistically significantly so.)

The second pair of results in Table 3 compares the impacts at two-year and four-year colleges. Arguably, we might expect the D.C. TAG program to have had larger effects on fouryear college enrollment than at two-year colleges, since the University of District of Columbia continued to provide D.C. residents seeking that type of education a lower cost option. As reported in Table 1, even after including the D.C. TAG grants, the tuition at public two-year colleges in Maryland and Virginia averaged \$4,085 in 2000 as opposed to \$2163 at UDC. The estimates are large and statistically significant at four-year colleges and not at two-year colleges. However, the small number of two-year colleges enrolling D.C. residents makes it difficult to identify the difference in responses.

The third pair of results in Table 3 compares the estimated impact of the D.C. TAG program among institutions that were more than 50 percent black in 1998 (before the change in policy) and those that had fewer African American students. The point estimates are larger for institutions that were more than 50 percent African American in 1998 (although only the difference in coefficients for the 1998 through 2002 period was statistically significant). 
It is worthwhile noting that, if one were focusing on changes in the absolute numbers of D.C. residents enrolled (or shares of D.C. residents enrolled in various institutions rather than log changes), one may have had the impression that enrollment was much more responsive at the historically black institutions. The top panels of Figure 1 report the change in the absolute numbers of D.C. residents attending individual institutions between 1998 and 2000, for institutions that were predominantly black in 1998 on the left and for institutions that were predominantly white on the right. The figure also reports the results of a regression of the change in absolute numbers of D.C. residents enrolled on the change in price, estimated separately for institutions that were greater than and less than 50 percent African American in 1998. With the absolute number of D.C. freshmen as the dependent variable, the coefficient on the change in tuition is 20 times larger for schools that were predominantly African American in 1998. (The coefficient was -12.33 with a standard error of 5.27 for the 11 predominantly black 4-year colleges in D.C., Maryland and Virginia; and -.63 with a standard error of .3 at 57 predominantly white 4-year colleges.) Using log enrollment at the dependent variable, the coefficient on tuition was 3 times as large for predominantly African American institutions (-.32 with a standard error of .12 for predominantly black 4-year colleges in D.C., MD and Virginia and -.10 with a standard error of .03 for predominantly white institutions. $)^{12}$ The large increases in absolute numbers of D.C. freshmen occurred at Virginia State University, Norfolk State and Morgan State and the largest declined occurred at Howard University and Hampton Universityall predominantly African American institutions. At the same time, Virginia Commonwealth

\footnotetext{
${ }^{12}$ When compared to the results in Table 2, these regression results also suggest that the impacts were considerably larger if one limited the sample to institutions in Maryland, Virginia and D.C..
} 
University, George Mason University and Old Dominion University saw large percentage increases in enrollment in response to the change in policy even if the change in absolute numbers of D.C. freshmen was small.

The last pair of results in Table 3 reports the results for selective and non-selective institutions, using as the metric of selectivity the $75^{\text {th }}$ percentile SAT math score of the students at the college. The impact of the program on enrollment appeared to be much larger at the nonselective institutions (and statistically significantly so when the results are pooled for the 1998 to 2002 period).

Table 4 reports the D.C. freshmen enrollment figures (for recent high school graduates) for the 12 selective colleges in Maryland and Virginia reporting $75^{\text {th }}$ percentile math SAT scores above 650. At George Washington, Georgetown and Howard, there were large declines in absolute numbers of D.C. freshmen enrolled between 1998 and 2000 (with some rebound between 2000 and 2002 at Georgetown and Howard). However, with the exception of the University of Maryland-College Park, the increases were minimal-- both in absolute numbers and in percentage terms at the other institutions. For example, at the University of Virginia, the absolute number of freshmen from D.C. remained at 13 to 14 . Even at the University of Maryland, where the percentage increases were more in line with increases at public institutions elsewhere, the changes in absolute numbers were quite small-from 13 to 25 and back to 18 between 1998 and 2002.

One reason may be the high admission standards for out-of-state students at the selective 
public institutions in Maryland and Virginia. ${ }^{13}$ At the University of Maryland, enrollment of non-resident students is capped at 25 percent. At the University of Virginia, the admission rate for state resident applicants for the fall of 2002 was nearly twice the rate for out-of-state students: approximately 53 percent of resident applicants were admitted, compared to 30 percent of non-residents. ${ }^{14}$ There is currently no explicit cap on non-resident enrollment at public colleges in Virginia. However, there are frequent proposals in the Virginia legislature to impose such a cap of 25 percent and university officials are certainly aware of the likely political consequences of allowing the number of non-resident students to grow. (Currently, about one third of University of Virginia undergraduates are from out of state.) Such implicit political pressure may be the cause of the higher standards for non-resident students (otherwise, many public institutions have a strong incentive to admit out-of-state students because they receive more tuition dollars for doing so). ${ }^{15}$

\section{Impacts on Applications and Enrollment in Federal Financial Aid Data}

In this section, I report on an analysis of federal financial aid applications from D.C., Maryland and Virginia during the 1998-99 through 2001-02 school years. I focus on dependent students, for whom both the parent and the student reported the same state of legal residence on the financial aid application. I limited the sample to first-year students, who report that they

\footnotetext{
${ }^{13}$ Some institutions are adjusting their admission requirements for D.C. residents. For example, the D.C. TAG program reports that North Carolina A\&T has adjusted it's admission requirements for D.C. residents to match the criteria for North Carolina residents.

${ }^{14}$ University of Virginia, Office of Admissions, www.virginia.edu/stats\&facts/

${ }^{15}$ For a description of recent calls for such a cap in Virginia, see Walzer (2003).
} 
have not attended college before.

On the Free Application for Federal Student Aid (FAFSA), applicants are allowed to list up to 6 institutions to which they want their financial aid information sent. Table 5 reports the proportions of financial aid applicants from the District of Columbia and from each of the states requesting that their financial information be sent to a public college in Maryland or Virginia. The table also reports the proportion of applicants having their data sent to public institutions elsewhere in the country and the number of schools the applicants listed on their FAFSA application. There was a 16 percentage point increase in the proportion of D.C. financial aid applicants requesting to have their information sent to a public institution in Maryland or Virginia and an 12 percentage point increase in the proportion of D.C. financial aid applicants having their information sent to any public institution outside D.C.. Over the same time period, there were minimal changes in the proportion of Virginia and Maryland applicants sending their scores to such institutions. As a result, as reported in the bottom panel, the difference-in-differences in application rates between states and over time imply a 16 and 12 percentage point increase in the proportion of financial aid applicants having their information sent to a Maryland or Virginia public institution and any public institution outside D.C. respectively after the D.C. TAG program started.

Table 5 also reports the number of schools listed on FAFSA applications from all three states. Between 1998 and 2001, applicants in all three states began sending information to more schools, but the increase was larger for applicants from D.C. As noted above, such changes in application behavior may partially reflect students' decisions to purchase options on attendance at desirable public institutions. 
Figures 2 and 3 portray the trends in application rates for residents of D.C., Maryland and Virginia. The top left panel of Figure 2 portrays the proportion of D.C. residents listing a Maryland or Virginia public institution on their FAFSA, which was stable between the 1998-99 school year (listed as 1998 in the graph) and the 1999-2000 school year, but rose sharply in 2000-01 and 2001-02 from 35 to 46 percent. There was little change for residents of Virginia or Maryland. The top right panel reports the proportion of D.C. residents listing a public institution outside of D.C., Maryland or Virginia. The number of D.C. residents applying to public institutions in other states declined from 1999 to 2000 from 36 percent to 34 percent (when only public institutions in Maryland and Virginia were eligible) and rose between 2000 and 2001 from 34 to 39 percent (when public institutions outside of Maryland and Virginia became eligible).

The bottom two panels report the trends in the proportion of FAFSA applicants listing a private institution qualifying for the $\$ 2500$ grants under the D.C. TAG program. The proportion of D.C. residents listing a private historically black institution in D.C., Maryland or Virginia on the FAFSA remained steady at approximately 20 percent between 1998 and 2001. The proportion listing one of the private non-black institutions in the D.C. area that qualified for the $\$ 2500$ grants actually declined from 17 percent in 1999-00 to 12 percent in 2001-02 school year.

Figure 3 portrays the proportion of dependent FAFSA applicants in each state applying to the types of institutions that did not qualify for a D.C. TAG grant. The proportion of D.C. residents applying to a private historically black institution outside D.C., Maryland and Virginia remained constant at about 15 percent between 1999 and 2001, while the proportion of D.C. residents applying to private non-black institutions outside the D.C. area declined sharply, from 
42 percent in 1999-00 to 32 percent in 2001-02. The proportion of D.C. residents listing a private, for-profit institution on the FAFSA form also declined sharply from 19 percent to 14 percent. Over the same time period when the application behaviors of D.C. residents were changing, the proportion of Maryland and Virginia residents applying to these institutions remained stable.

Figure 4 plots the proportion of FAFSA applicants listing a public institution in Maryland or Virginia on their financial aid forms, by family income, state or residence and year. (I divided the sample using $\$ 10,000$ intervals of family income up to $\$ 150,000$ and then included all of those with incomes above $\$ 150,000$ in one group.) As reported in the top left panel, the proportion of D.C. residents listing a public institution in Maryland or Virginia on their FAFSA form was quite similar in 1998 and 1999, and typically declining slightly in family income. Between 1999 and 2000, when the D.C. TAG program was created, the rates for all groups rose sharply and remained high in 2001. In the first year of the program, the increase was larger for middle income families with incomes from $\$ 50,000$ to $\$ 120,000$ and for low-income and highincome families. Between 1999 and 2000, however, the rates rose for low-income families, with an increase approximately as large as for middle income families. The increase remained small for families with incomes above $\$ 150,000$.

Table 6 reports the results from several probit specifications. The dependent variable is a binary measure of whether or not an applicant applied to a public college in Maryland or Virginia. The table reports the marginal impacts on the probability of applying to a Maryland or Virginia public institution. The marginal impacts of the interaction between D.C. and the year dummy variables measure the differential change in application behavior for D.C. residents 
relative to Maryland and Virginia residents. (The baseline difference is the difference that existed in 1999, the year prior to the D.C. TAG program's establishment.) The first column includes no other regressors, and suggests a 10 percentage point differential increase in the probability of applying to a Maryland or Virginia public institution for D.C. residents between 1999 and 2000. The difference grew to 14 percentage points in 2001.

The second column of Table 6 includes regressors-- including dummy variables for parental education, income categories, asset categories and an indicator for those with a zero expected family contribution (which would have qualified them for a maximum Pell grant). The point estimates on the effects of year do not change substantively, implying that there was little differential change in the composition of the applicant pool between 1999 and other years.

The remaining columns in Table 6 report estimates for various subsamples-- those with parents with no college education, parents with some college education, those with family incomes less than $\$ 75,000$, those with family incomes greater than or equal to $\$ 75,000$ and those with zero expected family contributions. The results suggest that in the first year of the program, the marginal impacts on the likelihood of applying to a Maryland or Virginia public institution seemed to be somewhat larger for those from higher family income levels and those with parents with some college. However, by the second year of the program, the estimated impact for all subgroups was in the range of 12 to 18 percentage points.

\section{Impacts on College Choice by Pell Grant Recipients}

For the subset of financial aid applicants receiving a federal Pell Grant, I also observed the college which the student subsequently attended. The Pell Grant program is the main 
federal means-tested grant program for undergraduate college students. Eligibility for Pell Grants was expanded between 1998 and 2001, as the maximum Pell Grant was raised from $\$ 3,000$ to $\$ 3,750$. In order to focus on similar students over time, I limit the sample to those with Expected Family Contributions less than $\$ 2600$ - a group that would have been eligible in all four years. Among this group, the median family income was $\$ 22,403$ in the three states. (The $10^{\text {th }}$ percentile family income was $\$ 6068$ and the $90^{\text {th }}$ percentile was $\$ 39,171$.)

In Figures 5 and 6, I report the proportion of Pell Grant recipients from D.C., Maryland and Virginia attending various types of institutions over time. As reported in Figure 4, the proportion of Pell Grant recipients from D.C. attending public institutions in Maryland or Virginia doubled in the first year of the program, from 14 percent to 30 percent, and remained at 30 percent in 2001. Moreover, the proportion of Pell Grant recipients from D.C. attending public institutions anywhere outside D.C., Maryland and Virginia actually declined by roughly one-third in the first of the program from 12 percent to 8 percent (when public institutions in these other states were only added late in the spring) and bounced back from 8 percent to 13 percent between 2000 and 2001 (when these public institutions nationwide were eligible).

Although private institutions in D.C. were eligible for $\$ 2500$ awards, these schools typically lost enrollment of low-income D.C. residents. The proportion of D.C. Pell Grant recipients attending private institutions in the D.C. area declined from 8 percent in 1998 and 1999 to 6 percent in 2000 and 2001. The proportion attending private historically black institutions in D.C., Maryland and Virginia also declined from 5 percent to 4 percent.

However, the biggest declines in enrollment of low-income students from D.C. occurred 
at private non-black institutions outside D.C. and for-profit proprietary schools. The proportion of D.C. Pell Grant recipients attending private non-black institutions outside D.C. declined from 17 to 10 percent. And the proportion of D.C. Pell Grant recipients attending proprietary schools declined from 23 percent in 1999 to 14 percent in 2001.

Table 7 reports results the marginal effects for a series of binary variables measuring the type of college attended by Pell Grant recipients. I use the same difference-in-difference approach used in Table 6, while including the full set of other covariates for family income, assets, parental education and an indicator for zero expected family contribution status. As reported in Table 7, there was a 17 percentage point differential rise in the proportion of D.C. resident Pell Grant recipients attending public institutions in Maryland or Virginia. Moreover, there were sizeable declines in the proportion of D.C. Pell Grant recipients attending private non-black institutions outside of Maryland and Virginia and attending for-profit proprietary schools. Interestingly, there was no substantial change in the proportion of Pell Grant recipients attending the University of the District of Columbia.

\section{Impacts on College Entry}

The results above suggest that the D.C. TAG program had a large impact on the types of colleges chosen by D.C. residents. However, there has also been a large increase in the proportion of youth from D.C. choosing to enter any college. Figure 7 reports the proportional increases in the number of D.C., Maryland and Virginia students reported as first-time freshmen (recent high school graduates) in the IPEDS data, the number of FAFSA applications filed by dependent first-time college students and the number of first-time college students who received 
a Pell Grant. Between 1998 and 2002, there was a 23 percent increase in the number of D.C. residents reported as first-time freshmen by colleges and universities around the country. Between 1999 and 2001, there was a 15 percent increase in the number of FAFSA applications submitted by dependent first-time freshmen in the District of Columbia. Moreover, there was a 21 percent increase in the number of first-time freshmen Pell Grant recipients from the district. ${ }^{16}$ All three increases were considerably larger than the changes observed in Maryland or Virginia. Over the same time period the number of graduates from D.C. public high schools remained flat. $^{17}$

The D.C. Tuition Assistance Grant program created a number of low-cost options that had not previously been available to residents of the district. Kane (1999) used variation in tuition at public 2-year and 4-year colleges across states to evaluate the impact on college enrollment using the cross-section of the National Education Longitudinal Study. According to Table 1, the D.C. TAG program lowered the tuition cost for D.C. residents of public 2-year and 4-year colleges in Maryland and Virginia by $\$ 3000$ and $\$ 6200$ respectively. Based only on the cross-sectional variation in state tuition policies, the estimates in Kane (1999) would have implied a 25 percentage point rise in college enrollment. ${ }^{18}$ Therefore, the increases in

${ }^{16}$ I am only counting Pell Grant recipients with EFC's below 2600. As a result, this is not simply due to the growth in the Pell Grant maximum over time.

${ }^{17}$ The number of D.C. public high school graduates from 1998 through 2002 were 2,777, $2,675,2,695,2,808,2,894$.

${ }^{18}$ Table 4-5 on page 104 of Kane (1999) reports coefficients of -.045 and -.008 on the tuition (in 1996 dollars) of public 2-year and 4-year college enrollment respectively. Adjusting for inflation using the CPI-U and multiplying the 2 year and 4-year price declines by the relevant coefficient would predict a 16.8 percentage point decline in enrollment rates. Dividing by a base enrolment rate of .68 yields a predicted percentage increase in enrollment of 25 percent. 
enrollment, applications and Pell Grant recipients that occurred following the creation of D.C. TAG program seem consistent with prior cross-sectional estimates.

However, it may not be appropriate to attribute all of the increase to the D.C. Tuition Assistance Grant program. The D.C. College Access Program (D.C. CAP)- a private program funded primarily by corporations and foundations-also began operations in 6 public high schools in D.C. for those graduating in the spring of 2000. The program was expanded to all D.C. public high schools the following year. The program provided college counselors in the high schools and "retention advisers" to help students remain in college. The program also provided \$2.2 million in scholarships to D.C. residents in the 2002-03 school year (compared to \$17 million for the D.C. TAG program that year).

The D.C. CAP program probably accounts for some share of the increase in enrollment observed over the time period. The expansion of the D.C. CAP program to all the district public high schools in the fall of 2000 corresponded with the rise in the proportion of low-income D.C. residents applying to public institutions in Maryland and Virginia, reported in Figure 4. But the D.C. CAP program probably does not account for all of the increase. Recall that much of the rise in college enrollment for D.C. residents seemed to occur for those graduating in 2000 , when D.C. CAP would have been serving only 6 of the 16 public high schools in D.C..

\section{Distributional Impacts}

When subsidizing public institutions, states typically offer the same low-tuition policies to all resident students, regardless of need. Similarly, the D.C. TAG program is not meanstested. But because the program is not means-tested, it is not possible to directly measure the 
income or family background of recipients of D.C. TAG grants. ${ }^{19}$ Rather, eligibility is based on domicile. As a result, I use the domicile information to identify the characteristics of the neighborhoods in which the D.C. TAG recipients were living.

Out of 4980 observed ever receiving a D.C. TAG grant at some point between 2000-2002 (those receiving grants in multiple years are counted only once), domicile data were matched to block group identifiers from the 2000 Decennial Census for 96 percent of the cases. There were 426 block groups within the District of Columbia, with a median population of 1100 in the 2000 census. $^{20}$

The panel on the right of Figure 8 identifies the locations of D.C. TAG recipients within the District of Columbia. ${ }^{21}$ (To protect confidentiality, each dot represents 5 recipients. The dots were randomly dispersed within the block groups in which they were located.) Block groups were shaded according the the ratio of the number of D.C. TAG recipients to the population aged 15 to 18 in the tract. (Darker shades imply more D.C. TAG recipients per population aged 15 to 18.) The map on the left is shaded according to the median household income in the tract. (Darker shades imply higher incomes.)

As is evident in the graph, recipients were drawn from all over the district. Moreover,

\footnotetext{
${ }^{19}$ They do collect tax returns to confirm families' domicile. Such data could potentially be used to identify incomes of recipients. Moreover, in 2003-04, they began to collect information on the incomes of applicants, but such data were not available for the early years of the program.

${ }^{20}$ Of these 426 neighborhoods, 28 block groups with more that 50 people living in college dormitories- presumably parts of college campuses-- were dropped.

${ }^{21}$ In a January 2002 report, the General Accounting Office (2002) provided a map of the number of TAG applicants per population aged 18 to 24 by ward. There are 8 wards in the district.
} 
there is some evidence that recipient-to-population ratios were higher in some of the northwest D.C. neighborhoods with higher incomes. However, there were also a number of lower income neighborhoods which appeared to contain a large number of recipients. Beyond noting that recipients were widely dispersed within the district, it is difficult to tell from the presentation of data in Figure 8 just how correlated the recipiency rates were with neighborhood income.

To provide a clearer picture of the differences in receipt of D.C. TAG grants in high and low-income neighborhoods, I calculated the total number of new grants (not counting renewed grants) in each block group in each year. Then, for each block group, I calculated the ratio of the number of new grants in each year to the number of own and related children between the ages of 15 and 17 in the block group at the time of the 2000 census. ${ }^{22}$ Finally, I sorted each of the block groups into 10 deciles, based on median household income in the block group. Figure 9 reports the mean recipiency ratio for the census tracts in each of these neighborhood income deciles. (Table 8 reports the series used in the graph.)

There are three facts worth noting. First, the recipiency ratio rises substantially between the neighborhoods in the lowest decile and those in the $5^{\text {th }}$ decile. In the first year of the program, neighborhoods in the $5^{\text {th }}$ decile of neighborhood incomes (with a median household income of $\$ 31,194$ ) had a mean recipiency ratio roughly 3 times the recipiency ratio in the bottom decile (.125 versus .037).

The high recipiency ratios in middle and higher income neighborhoods reflects some combination of two effects: differences in the proportion of youth entering college and

\footnotetext{
${ }^{22}$ I used population data from the Census STF1 files. As an alternative, I also used the total number of own and related children under age 18 as a denominator with similar results.
} 
differences in the proportion of youth attending the types of institutions that qualify for the grants. As reported in Kane (1999), in the states that do provide large subsidies to public universities, some of the regressivity due to differences in college-going by income is offset by the fact that higher income families are also more likely to attend private colleges and universities, which receive less public money. Unfortunately, it is difficult to sort out these two effects using these data. Since college students no longer residing with their parents are not counted with the family household, it is not possible to identify the proportion of each neighborhood's children who are attending college.

Second, for the $5^{\text {th }}$ decile neighborhoods and higher, the differences in the recipiency associated with neighborhood are much smaller. For instance, the recipiency ratio in the highest decile neighborhoods (with a median household income of approximately \$114,390) was .140, only slightly higher than for the recipiency ratio for the middle decile. In fact, the recipiency ratio seems to peak around the $9^{\text {th }}$ decile and then decline between the $9^{\text {th }}$ and $10^{\text {th }}$ decile.

Finally, the differences in the neighborhood recipiency ratios seem to flatten out between 2000 and 2002. Notice that the flattening occurred because of a decline in recipiency ratios in middle income neighborhoods, rather than because of any increase in recipiency by lowerincome neighborhoods. In the first year of the program, any undergraduate college student meeting the eligibility requirements was eligible, as long as they had graduated from college after 1998. As a result, the new applicants in the first year included sophomores through seniors in college. After the first year, presumably, a larger share of the applicants for first-time college students. As long as college going rates and college retention rates are positively associated with family income, this could account for the flattening of the recipiency ratios as the program 
reaches its steady state.

\section{Conclusion}

The D.C. Tuition Assistance Grant program dramatically changed the menu of college prices offered to residents of the District of Columbia. Between 1998 and 2000, when the effective price of a public 2-year and 4-year college for reduced by $\$ 3,000$ and $\$ 6,200$ respectively, the number of D.C. residents attending public institutions inVirginia and Maryland more than doubled. When public institutions in other states were included in subsequent years, there were also large increases in D.C. students enrolling in public institutions in more distant states, although the percentage changes were smaller. The increases were largest at nonselective public 4-year institutions in the mid-Atlantic states, particular predominantly black public institutions.

When combined with the D.C. College Access Program which began providing more intensive counseling to high school students in the D.C. public schools at the same time, the D.C. TAG program also seems to have had a large impact on the proportion of D.C. residents entering college. The number of first-time federal financial aid applicants, the number of first-year college students receiving Pell Grants and the number of freshmen from D.C. reported by colleges and universities nationally all increased by 15 percent or more.

Although the program did seem to have an impact on the proportion of youth entering college, the program also led to an widespread reshuffling of students from private non-profit and proprietary schools, toward public colleges and universities, particularly in Maryland and Virginia. As Peltzman (1973) recognized, the net effect of in-kind subsidies to higher education 
(those that are limited to public higher education institutions) on bachelor's degree completion rates and total investments in higher education is ambiguous. On one hand, more people seem to be entering college. On the other hand, actual expenditures per student and BA degree completion rates tend to be lower at public institutions than at private institutions. The net effect of the D.C. TAG program on the proportion of D.C. residents completing higher education degrees and in the quality of education they receive remains to be seen. Future work will need to focus on changes over time on the eventual BA completion and the quality of education received by D.C. residents, by comparing the outcomes of those who graduated from D.C. high schools in 2000 and after with the outcomes for those who graduated in earlier years. 


\section{References:}

Abraham, Katharine G. and Melissa Clark "Financial Aid and Students' College Decisions: Evidence from the District of Columbia's Tuition Assistance Grant Program" Princeton University Education Research Section Working Paper \# 2, August 2003.

Cameron, Stephen V; Heckman, James J. "Life Cycle Schooling and Dynamic Selection Bias: Models and Evidence for Five Cohorts of American Males" Journal of Political Economy. Vol. 106 (2). p 262-333. April 1998

Card, David and Thomas Lemieux "Dropout and Enrollment Trends in the Post-War Period: What Went Wrong in the 1970's" NBER Working Paper 7658, April, 2000.

Dynarski, Susan. "Hope for Whom? Financial Aid for the Middle Class and Its Impact on College Attendance" National Tax Journal Vol. 53, No. 3 (September 2000) pp. 629-662.

Dynarski, Susan. "Does Aid Matter? Measuring the Effect of Student Aid on College Attendance and Completion" American Economic Review (March, 2003) Vol. 93, No. 1, pp. 279-288.

Hansen, W. Lee and Burton Weisbrod, "The Distribution of Costs and Direct Benefits of Public Higher Education: The Case of California" Journal of Human Resources (1969) Vol. 4, Spring, pp. 176-191.

Hansen, W. Lee and Burton Weisbrod, "On the Distribution of Costs and Benefits of Public Higher Education: Reply" Journal of Human Resources (1971) Vol. 6, No. 3, pp. 363374.

Hartman, Robert "A Comment on the Pechman-Hansen-Weisbrod Controversey" Journal of Human Resources (1970) Vol. 5, No. 3, pp. 519-523.

Kane, Thomas J. "College Attendance By Blacks Since 1970: The Role of College Cost, Family Background and the Returns to Education" Journal of Political Economy (1994) Vol. 102, No. 5, pp. 878-911.

Kane, Thomas J. The Price of Admission: Rethinking How Americans Pay for College (Washington, D.C.: Brookings Institution and Russell Sage, 1999).

Linsenmeier, David M., Harvey Rosen and Cecilia Rouse "Financial Aid Packages and College Enrollment Decisions: An Econometric Case Study" Princeton University Industrial Relations Section Working Paper No. 459, November 2001.

McFadden, Daniel "Conditional Logit Analysis of Qualitative Choice Behavior" in P. Zarembka 
(ed.) Frontiers in Econometrics (New York: Academic Press, 1974).

Pechman, Joseph A. "The Distributional Effects of Public Higher Education in California" Journal of Human Resources (1970) Vol. 5, Summer, pp. 361-370.

Pechman, Joseph A. "The Distribution of Costs and Benefits of Public Higher Education: Further Comments" Journal of Human Resources (1971) Vol. 6, No. 3, pp. 365-376.

Peltzman, Sam "The Effect of Government Subsidies-in-Kind on Private Expenditures: The Case of Higher Education" The Journal of Political Economy, Vol. 81, No. 1. (Jan. - Feb., 1973), pp. 1-27.

United States General Accounting Office, D.C. Tuition Assistance Grants: Program May Increase College Choices, but a Few Program Procedures May Hinder Grant Receipt for Some Residents, GAO Report 02-265, January 2002.

van der Klaauw, Wilbert. "A Regression-Discontinuity Evaluation of the Effect of Financial Aid Offers on College Enrollment" New York University Department of Economics mimeo, March 1997. (Revised April, 2001) Forthcoming in the International Economic Review under the title "Estimating the Effect of Financial Aid Offers on College Enrollment: A Regression-Discontinuity Approach"

Walzer, Philip "Portion of In-State Admissions Rises: Balance Responsibility to Virginians with Need for Diversity" The Virginian-Pilot (Norfolk, VA) March 31, 2003, p. B1. 
Figure 1.
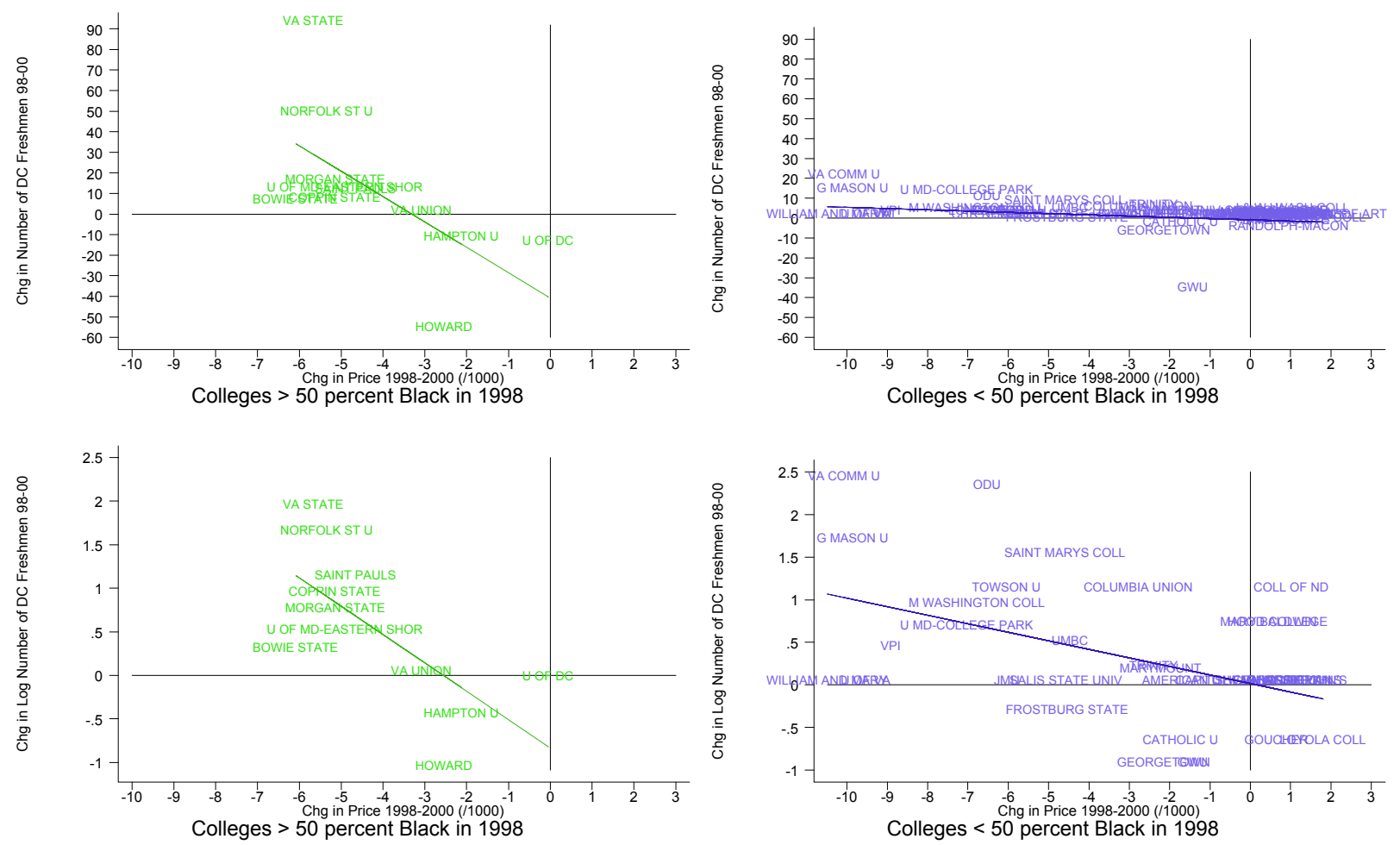

Absolute and Percentage Changes in DC Freshmen Enrollment 
Figure 2. Proportion of Dependent Federal Aid Applicants Listing An Institution on the FAFSA by Type of Institution, State and Year

(Institutions Eligible for D.C. TAG Grant)
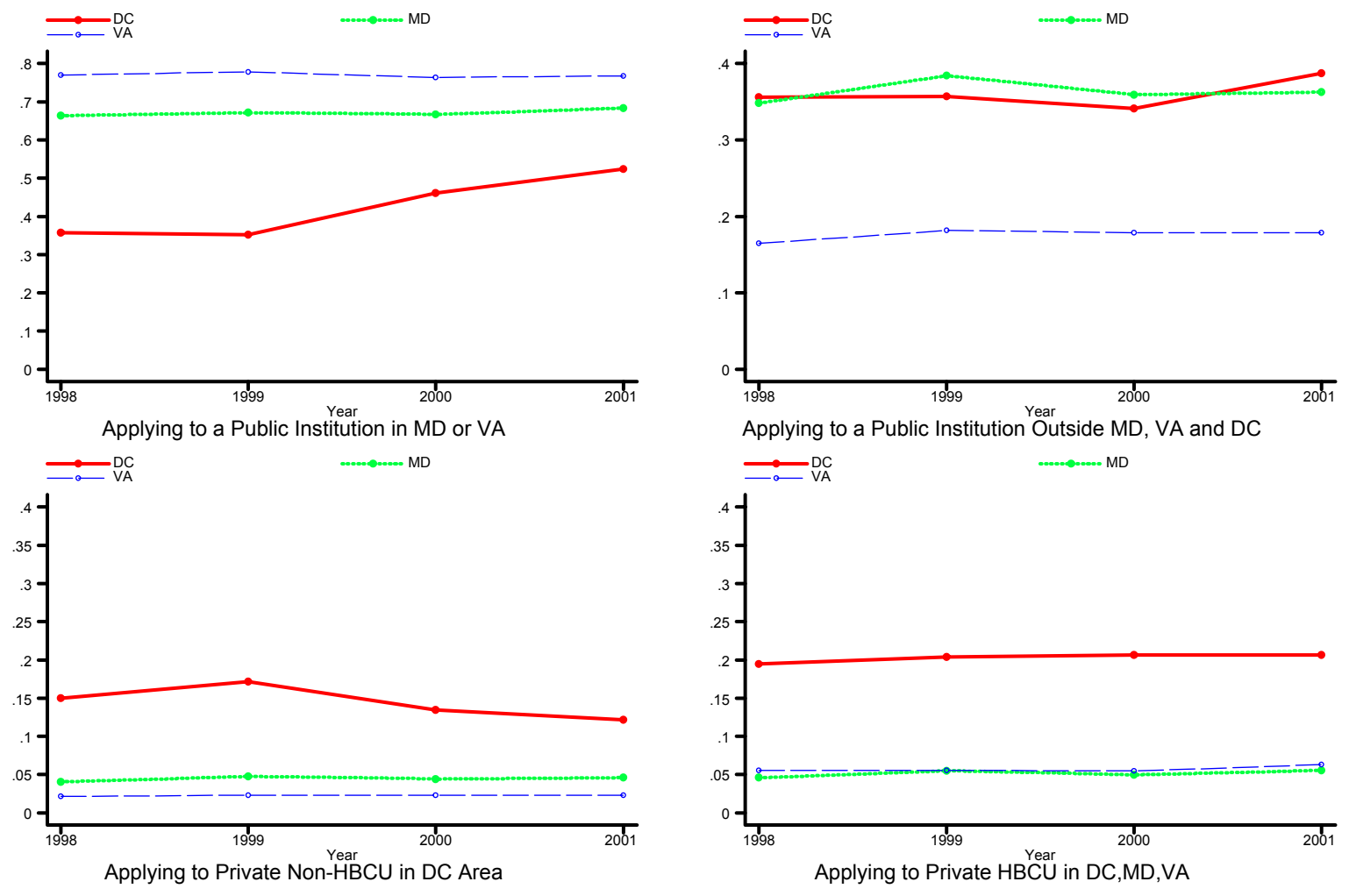
Figure 3. Proportion of Dependent Federal Aid Applicants Listing An Institution on the FAFSA by Type of Institution, State and Year

(Institutions Not Eligible for D.C. TAG Grant)
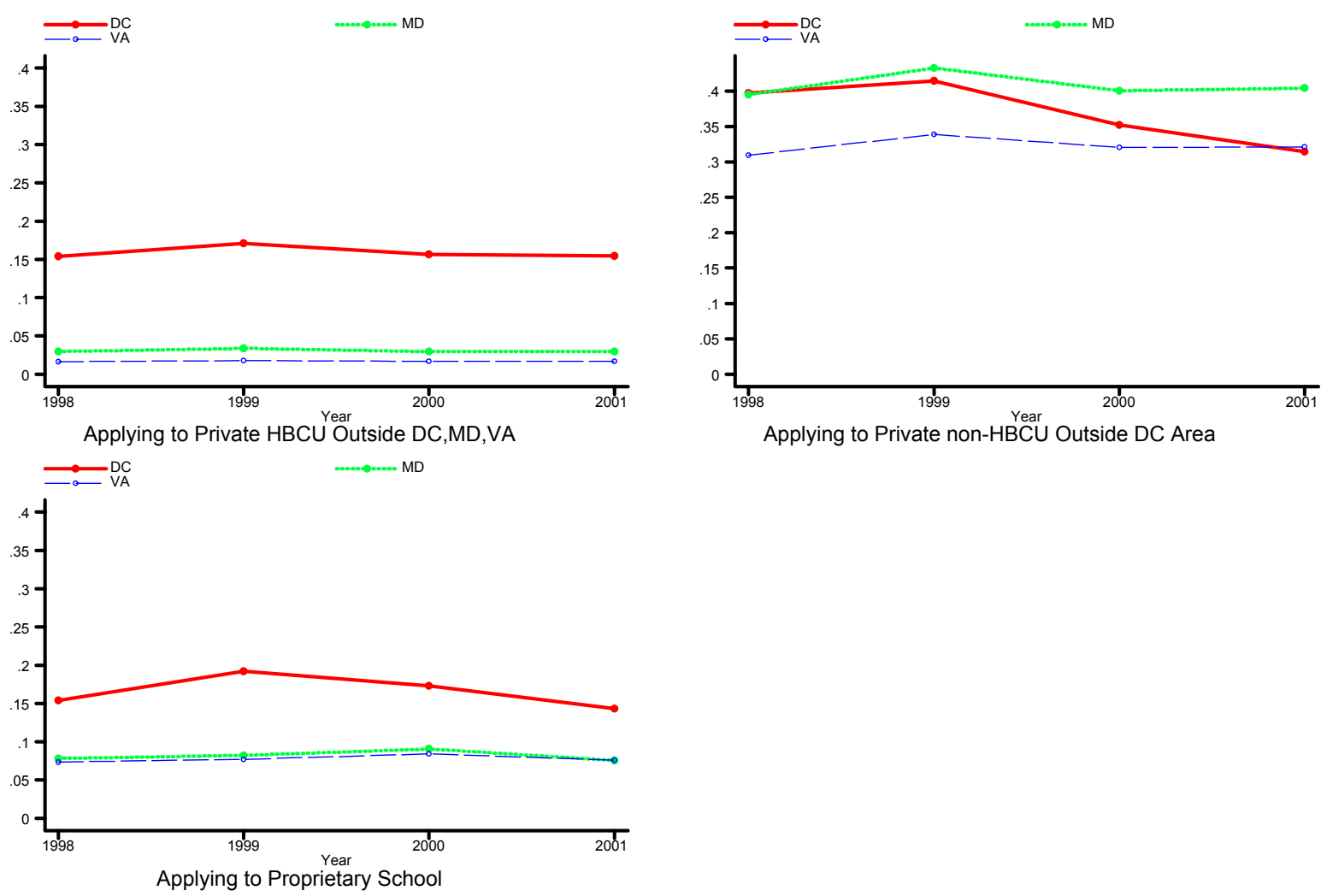
Figure 4. Proportion of FAFSA Applicants Listing a Public Institution in Maryland or Virginia by Family Income, State and Year
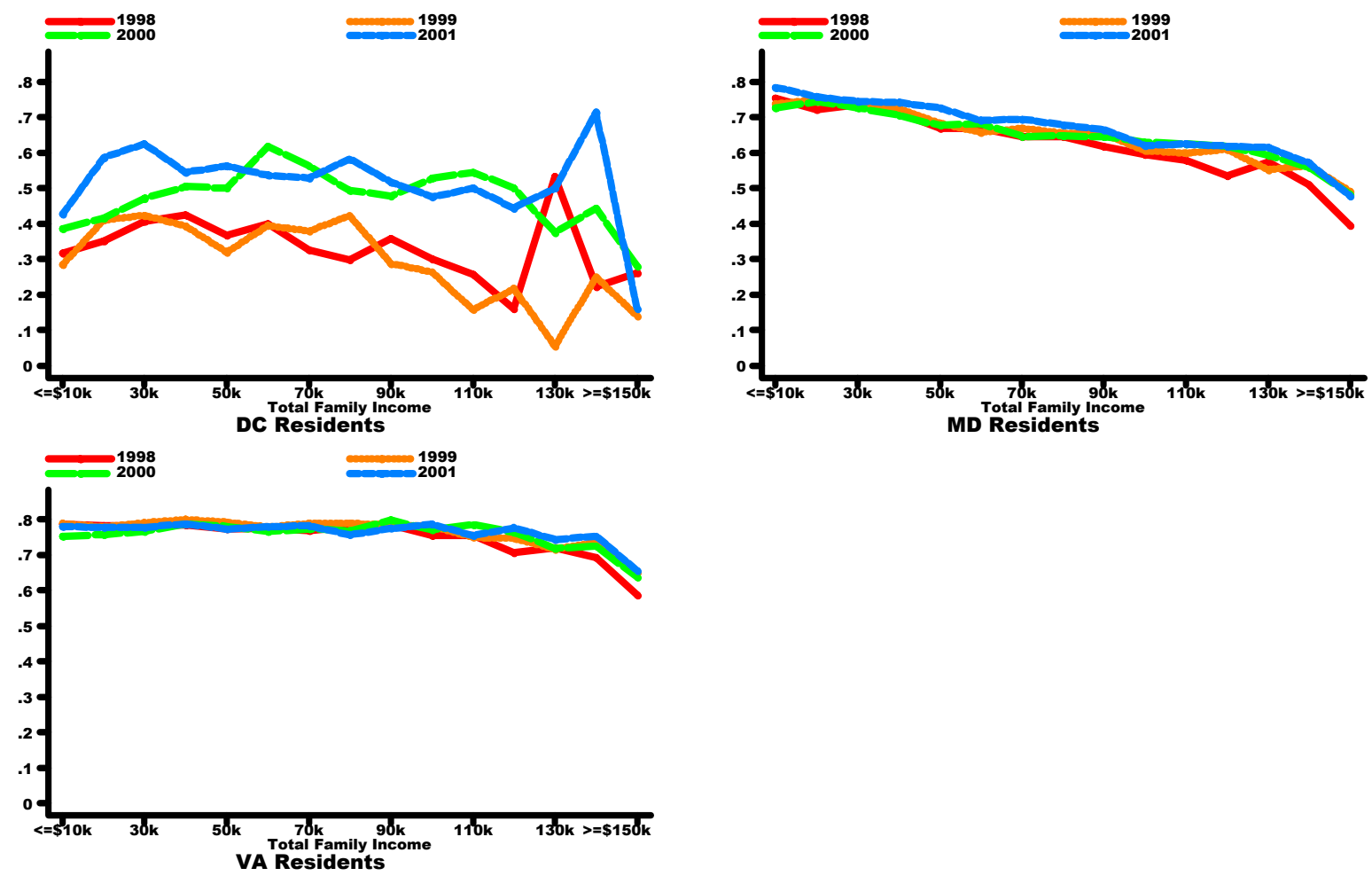

Applying to MD, VA Public Colleges by Income and Year 
Figure 5. Proportion of Pell Grant Recipients Attending by Type of Institution, State and Year

\section{(Institutions Eligible for D.C. TAG Grant)}
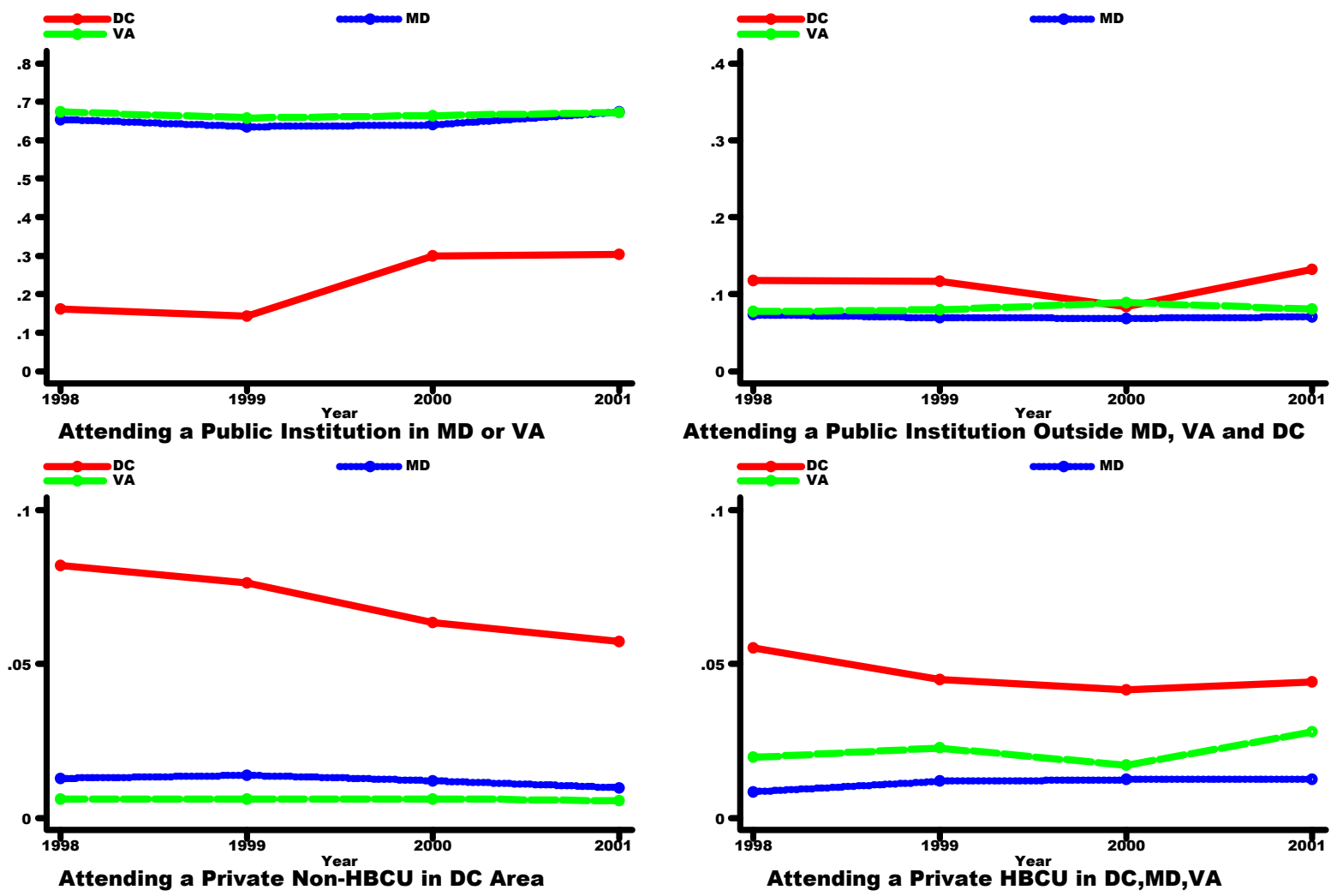

Attending a Public Institution Outside MD, VA and DC

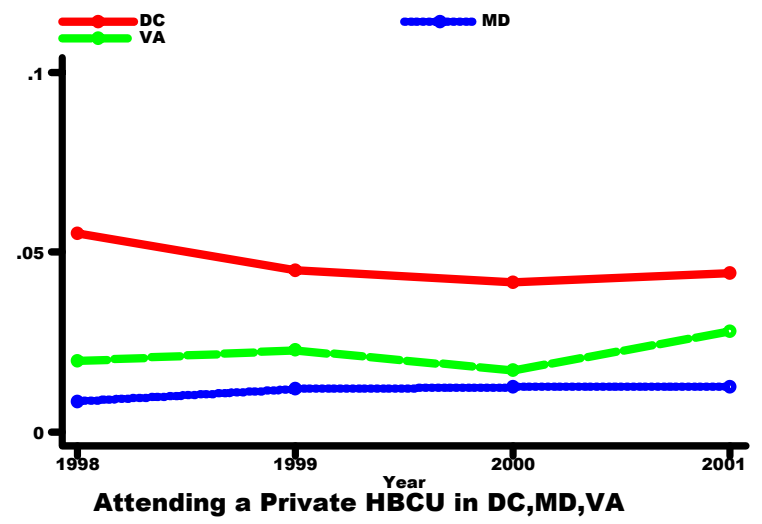


Figure 6. Proportion of Pell Grant Recipients Attending by Type of Institution, State and Year

(Institutions Not Eligible for D.C. TAG Grant)

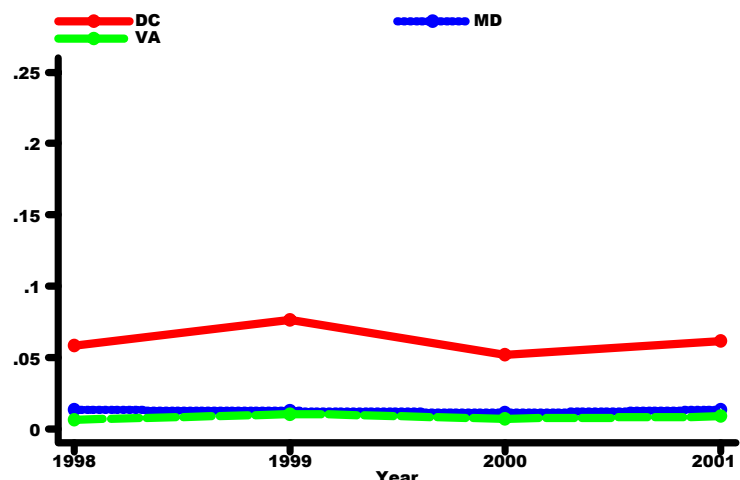

Attending a Private HBCU Outside DC, MD, VA
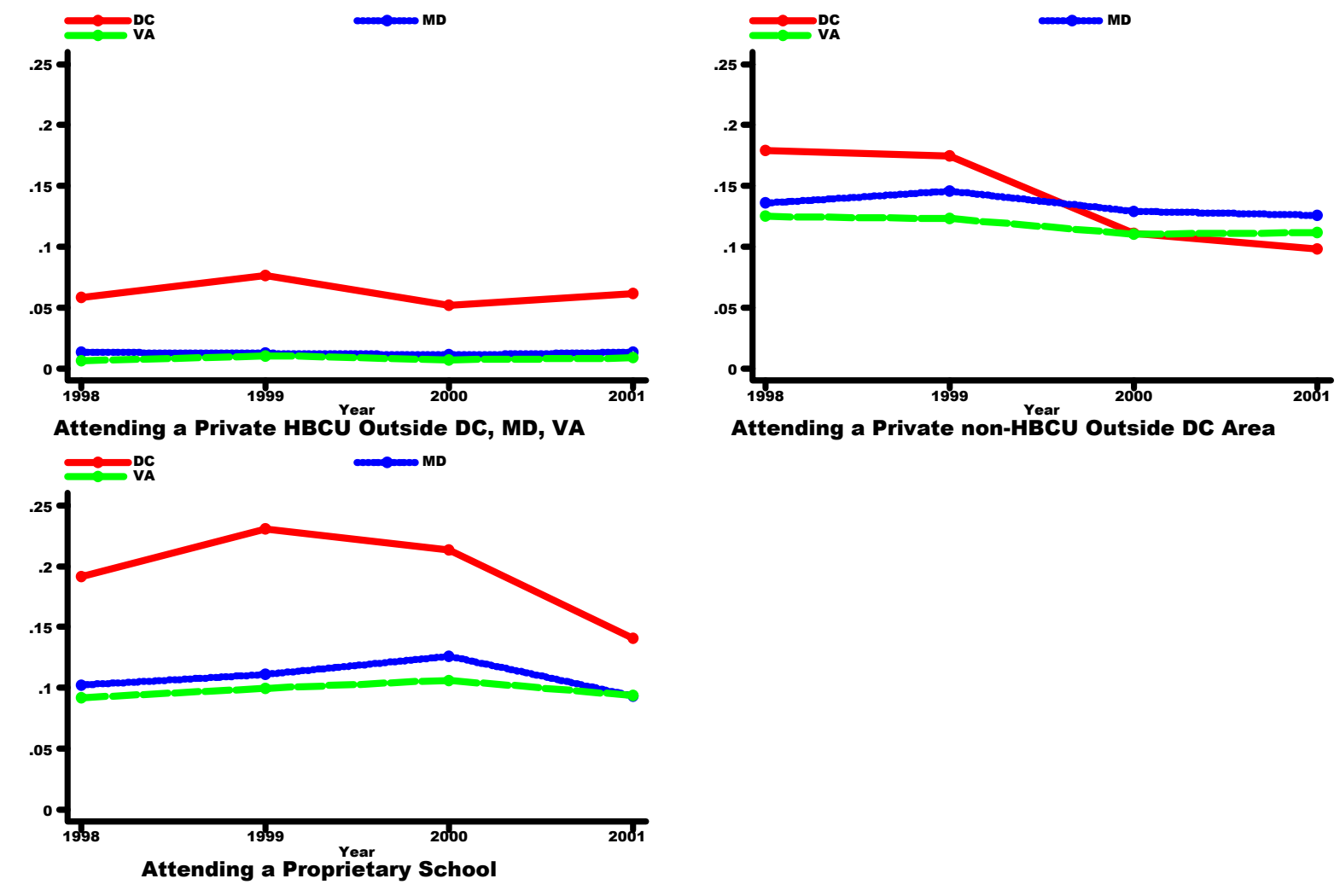

Attending a Private non-HBCU Outside DC Area 
Figure 7. Proportional Changes in Enrollment, Number of FAFSA Applications and Pell Grant Recipients by State and Year
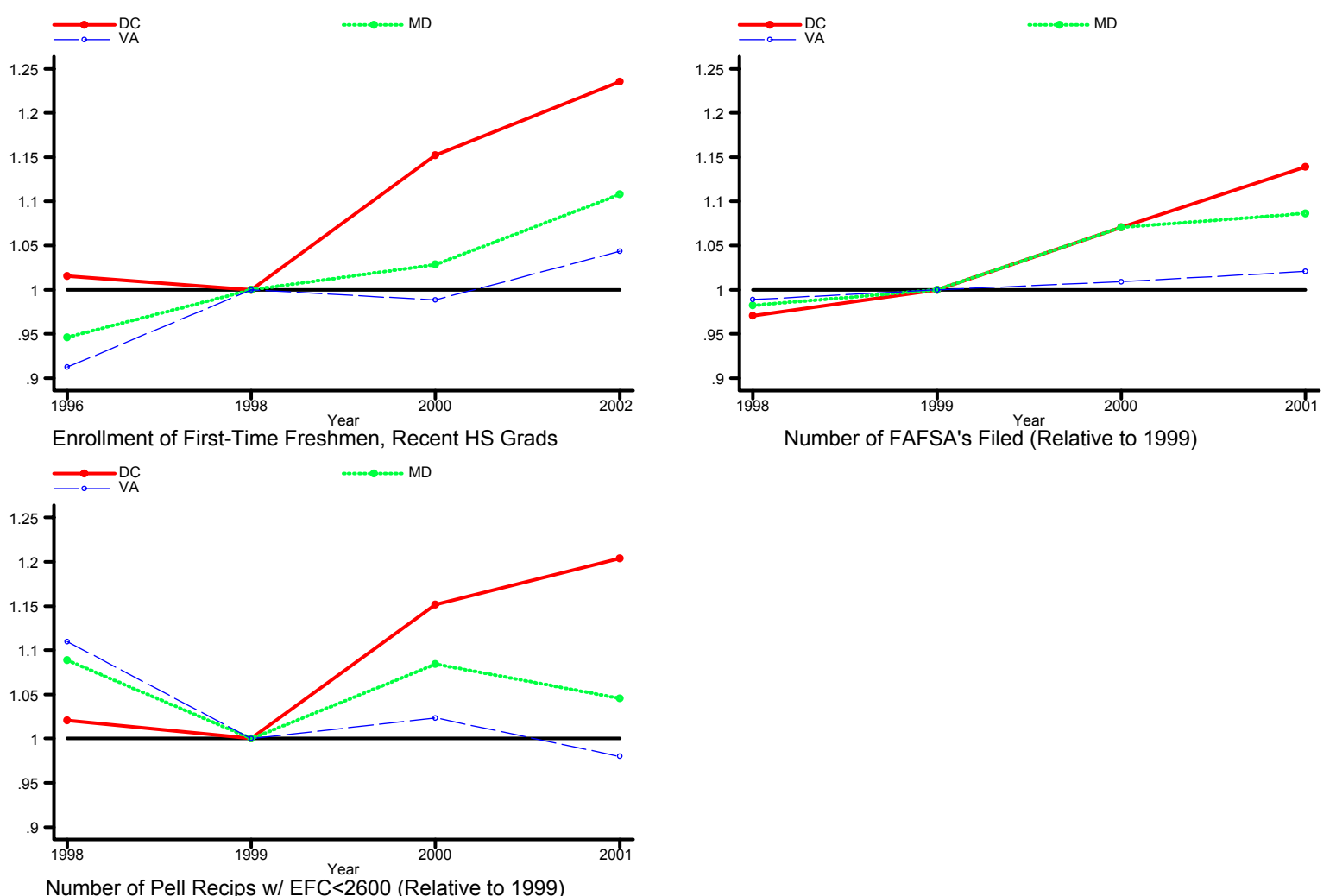


\author{
Figure 8.
}

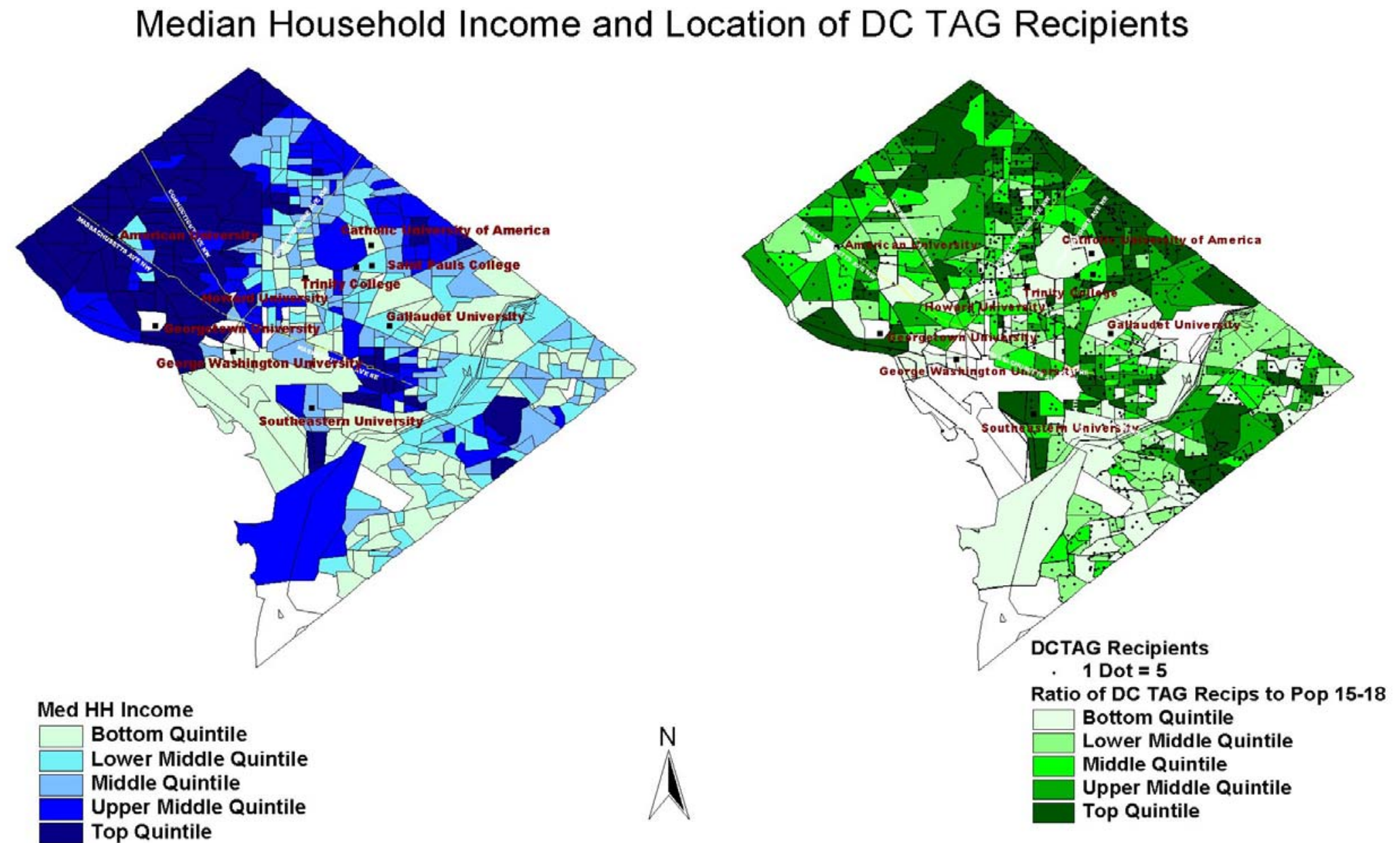


Figure 9.

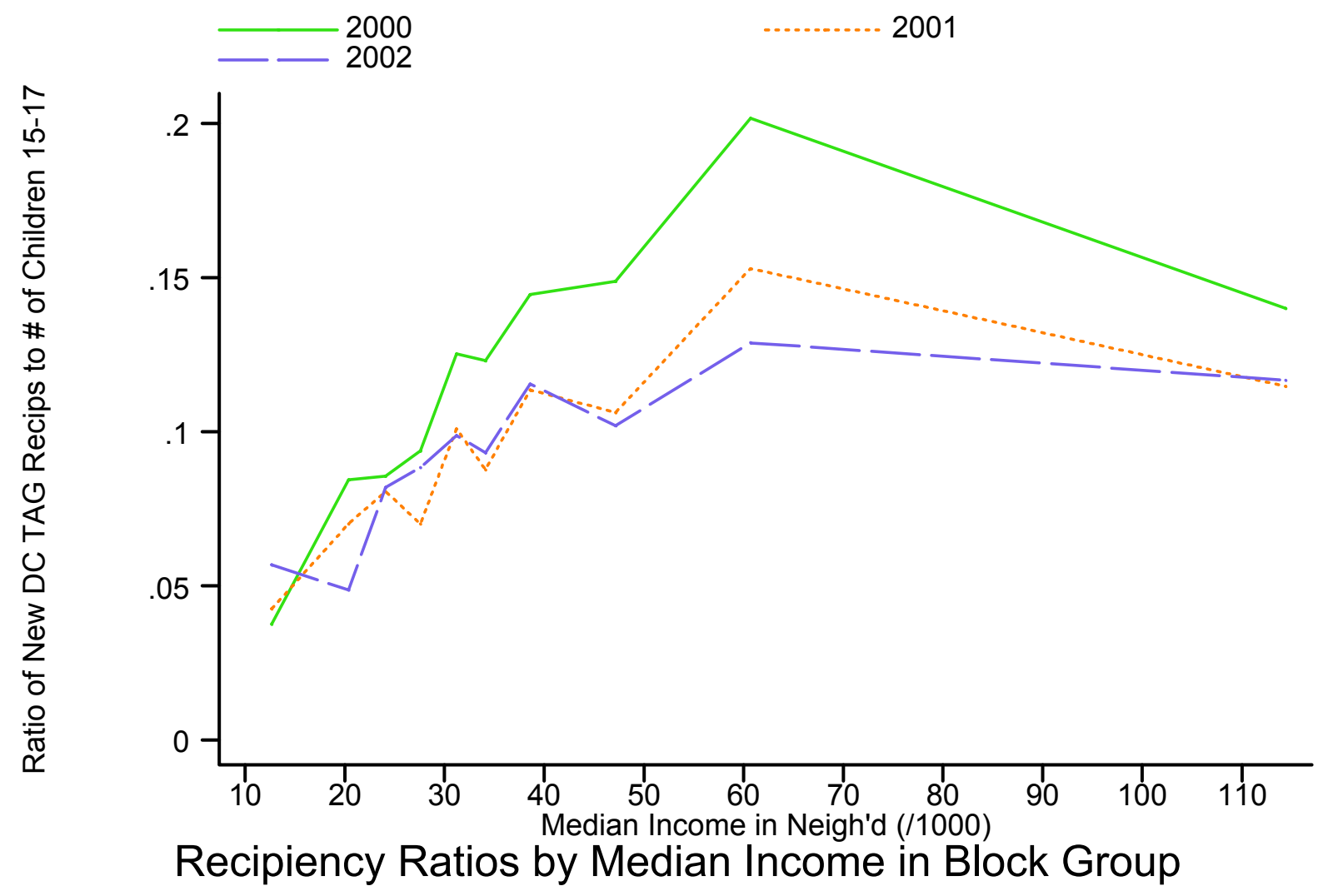




\section{Table 1. Relative Prices and Enrollments of DC Residents Before and After DC TAG}

\begin{tabular}{|c|c|c|c|c|c|c|c|c|c|}
\hline & \multirow{2}{*}{\multicolumn{3}{|c|}{$\begin{array}{l}\text { Tuition for DC Residents } \\
\text { (net of DC TAG) }\end{array}$}} & \multirow{2}{*}{\multicolumn{3}{|c|}{$\begin{array}{l}\text { Difference-in-Difference } \\
\text { Relative to UDC }\end{array}$}} & \multicolumn{3}{|c|}{ DC Freshmen Enrollment } \\
\hline & & & & & & & \multirow{2}{*}{$\begin{array}{r}\text { Enrollment } \\
1998\end{array}$} & \multirow{2}{*}{\multicolumn{2}{|c|}{$\begin{array}{c}\text { Change } \\
\text { 2000-1998 2002-2000 }\end{array}$}} \\
\hline & 1998 & 2000 & 2002 & $2000-1998$ & $2002-2000$ & 2002-1998 & & & \\
\hline Univ. of District of Columbia & $\$ 2,218$ & $\$ 2,163$ & $\$ 2,070$ & $\$ 0$ & $\$ 0$ & $\$ 0$ & 260 & -15 & -5 \\
\hline Priv, Non-HBCU, Outside DC & 21,289 & 21,829 & 23,115 & 595 & 1,379 & 1,974 & 428 & 50 & -66 \\
\hline Pub 4-Year in MD, VA & 10,783 & 4,515 & 5,201 & $-6,213$ & 779 & $-5,434$ & 146 & 252 & -59 \\
\hline Pub 2-Year in MD, VA & 7,126 & 4,085 & 3,994 & $-2,986$ & 2 & $-2,984$ & 30 & 35 & 5 \\
\hline Pub 4-Year in Other States & 10,063 & 10,219 & 4,614 & 211 & $-5,512$ & $-5,301$ & 286 & -53 & 245 \\
\hline Pub 2-Year in Other States & 2,876 & 3,129 & 1,465 & 308 & $-1,571$ & $-1,263$ & 6 & 5 & -4 \\
\hline Priv $\mathrm{HBCU}$ in $\mathrm{DC}, \mathrm{MD}, \mathrm{VA}$ & 10,373 & 7,807 & 8,161 & $-2,511$ & 447 & $-2,064$ & 139 & -60 & 0 \\
\hline Priv HBCU Elsewhere & 9,466 & 10,502 & 8,604 & 1,091 & $-1,805$ & -714 & 119 & -7 & 17 \\
\hline Priv Colleges in DC & 20,819 & 19,029 & 20,375 & $-1,735$ & 1,439 & -296 & 158 & -36 & 32 \\
\hline Total: & $\$ 12,830$ & $\$ 12,003$ & $\$ 11,394$ & $-\$ 772$ & $-\$ 516$ & $-\$ 1,288$ & 1,572 & 171 & 165 \\
\hline
\end{tabular}

Note: Based on tuition and enrollment data in IPEDS database and DC TAG program rules. Enrollment figures are reported for first-time freshmen who had graduated within the last 12 months. Tuition estimates net of DC TAG assumed that expansion of the program to public institutions outside of MD and VA was not effective until after 2000 . All figures in $\$ 2002$ using CPI-U-X1. Tuition figures were 


\section{Table 2. Fixed Effect Regressions of Log of DC Resident Enrollment on Price for DC Residents, 1998-2002}

\begin{tabular}{|c|c|c|c|c|c|c|}
\hline & $\begin{array}{r}\operatorname{Ln}(\text { Firs } \\
A \\
(>=1\end{array}$ & $\begin{array}{l}\text { t-Time Fres } \\
\text { II Institution } \\
\text { DC Reside }\end{array}$ & $\begin{array}{l}\text { hmen) } \\
\text { s } \\
\text { nts) }\end{array}$ & $\begin{array}{r}\operatorname{Ln}(\mathrm{F}-\mathrm{T} F \mathrm{Fr} \\
A \\
A^{>}=1\end{array}$ & $\begin{array}{l}\text { resh, Recer } \\
\text { II Institution } \\
\text { DC Reside }\end{array}$ & $\begin{array}{l}\text { ht HS Gr) } \\
\text { is } \\
\text { nts) }\end{array}$ \\
\hline & $2000-1998$ & $2002-2000$ & $2002-1998$ & $2000-1998$ & $2002-2000$ & $2002-1998$ \\
\hline $\begin{array}{l}\text { Tuition net of } \\
\text { DC TAG (/1000) }\end{array}$ & $\begin{array}{r}-0.075 \\
(0.032) \\
\end{array}$ & $\begin{array}{r}-0.052 \\
(0.018) \\
\end{array}$ & $\begin{array}{r}-0.054 \\
(0.012) \\
\end{array}$ & $\begin{array}{r}-0.095 \\
(0.032) \\
\end{array}$ & $\begin{array}{r}-0.062 \\
(0.020) \\
\end{array}$ & $\begin{array}{r}-0.063 \\
(0.014) \\
\end{array}$ \\
\hline Observations & 759 & 796 & 1180 & 632 & 655 & 960 \\
\hline & $>=1$ & o DC Resid & ents & $>=10$ & O DC Resid & lents \\
\hline $\begin{array}{l}\text { Tuition net of } \\
\text { DC TAG (/1000) }\end{array}$ & $\begin{array}{r}2000-1998 \\
-0.069 \\
(0.045) \\
\end{array}$ & $\begin{array}{r}2002-2000 \\
-0.105 \\
(0.030) \\
\end{array}$ & $\begin{array}{r}2002-1998 \\
-0.074 \\
(0.024) \\
\end{array}$ & $\begin{array}{r}2000-1998 \\
-0.075 \\
(0.061) \\
\end{array}$ & $\begin{array}{r}2002-2000 \\
-0.090 \\
(0.042) \\
\end{array}$ & $\begin{array}{r}2002-1998 \\
-0.080 \\
(0.035) \\
\end{array}$ \\
\hline Observations & 93 & 96 & 145 & 76 & 81 & 118 \\
\hline e: All re & in & umr & xed ef & & Th & $\begin{array}{l}\text { for DC } \\
\text { ide of } \\
\text { bite }\end{array}$ \\
\hline
\end{tabular}




\section{Table 3. Fixed Effect Regressions for Selected Subsamples of Log of DC Resident Enrollment on Price for DC Residents, 1998-2002}

\begin{tabular}{|c|c|c|c|}
\hline & \multicolumn{3}{|c|}{$\begin{array}{c}\text { Institutions in } \\
D C, V A, P A, M D, N C, N Y G A, D E\end{array}$} \\
\hline & $2000-1998$ & $2002-2000$ & $2002-1998$ \\
\hline $\begin{array}{l}\text { Tuition net of } \\
\text { DC TAG (/1000) }\end{array}$ & $\begin{array}{r}-0.099 \\
(0.032)\end{array}$ & $\begin{aligned}-0.082 \\
(0.027)\end{aligned}$ & $\begin{array}{r}-0.078 \\
(0.018)\end{array}$ \\
\hline \multirow[t]{3}{*}{ Observations } & 327 & 333 & 493 \\
\hline & \multicolumn{3}{|c|}{$\begin{array}{c}\text { Four-Year } \\
\text { Colleges and Universities }\end{array}$} \\
\hline & $2000-1998$ & $2002-2000$ & $2002-1998$ \\
\hline $\begin{array}{l}\text { Tuition net of } \\
\text { DC TAG (/1000) }\end{array}$ & $\begin{array}{r}-0.093 \\
(0.032) \\
\end{array}$ & $\begin{array}{r}-0.062 \\
(0.019) \\
\end{array}$ & $\begin{array}{r}-0.062 \\
(0.014) \\
\end{array}$ \\
\hline
\end{tabular}

Observations

602

623

918

Institutions with $>=50 \%$ Black

Enrollment in 1998

\begin{tabular}{|c|c|c|c|}
\hline & $2000-1998$ & $2002-2000$ & $2002-1998$ \\
\hline $\begin{array}{l}\text { uition net of } \\
\text { C TAG (/1000) }\end{array}$ & $\begin{array}{r}-0.177 \\
(0.062)\end{array}$ & $\begin{array}{r}-0.126 \\
(0.059)\end{array}$ & $\begin{array}{r}-0.133 \\
(0.041)\end{array}$ \\
\hline
\end{tabular}

Observations

85

87

130

Non-Selective Institutions

(75th Ptile Math SAT <650)
Institutions in

Other States

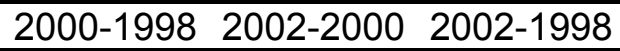

$\begin{array}{lll}0.083 & -0.051 & -0.042\end{array}$

$\begin{array}{lll}(0.125) & (0.027) \quad(0.020)\end{array}$

305

322

467

Two-Year

Colleges

\begin{tabular}{rrr}
\hline $2000-1998$ & $2002-2000$ & $2002-1998$ \\
\hline 0.134 & -0.003 & -0.036 \\
$(0.406)$ & $(0.064)$ & $(0.141)$ \\
\hline
\end{tabular}

30

32

42

Institutions with $<50 \%$ Black Enrollment in 1998

\begin{tabular}{rrr}
\hline $2000-1998$ & $2002-2000$ & $2002-1998$ \\
\hline-0.083 & -0.052 & -0.056 \\
$(0.038)$ & $(0.022)$ & $(0.015)$ \\
\hline
\end{tabular}

547

567

829

Selective Institutions (75th Ptile Math SAT >=650)

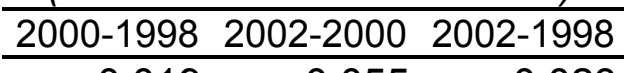

$\begin{array}{lll}-0.019 & -0.055 & -0.023\end{array}$

(0.027)

(0.033)

(0.017)

$\begin{array}{llll}\text { Observations } & 313 & 322 & 471\end{array}$

$196 \quad 207$

305

Note: All regressions include year dummies and fixed effect for each institution. The data are based on tuition and enrollment data in IPEDS database and DC TAG program rules. In estimating tuition for DC residents net of DC TAG, I assumed that the expansion of the program to public institutions outside of MD and VA not effective until 2001. All tuition figures in 2002 dollars using CPI-U-X1. Huber-White heteroskedasticity-robust standard errors reported. 


\section{Table 4. DC Freshmen Enrollment at Selective Institutions in DC, Maryland and Virginia}

(Schools with 75th Percentile SAT Math Scores > 650)

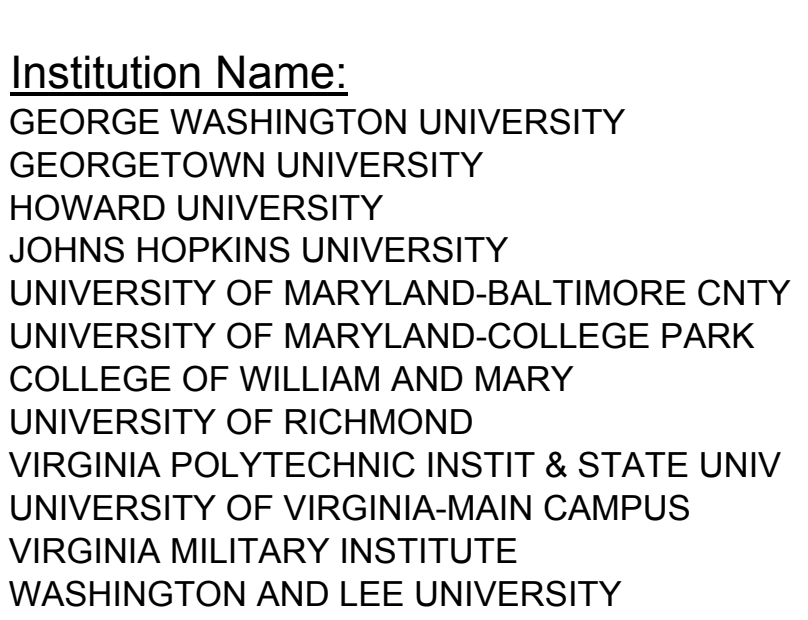

\begin{tabular}{|c|c|c|c|c|}
\hline 1998 & 2000 & 2002 & $\begin{array}{c}\text { Change } \\
1998-2000\end{array}$ & $\begin{array}{c}\text { Change } \\
2000-2002\end{array}$ \\
\hline 60 & 23 & 17 & -37 & -6 \\
\hline 13 & 5 & 24 & -8 & 19 \\
\hline 86 & 29 & 48 & -57 & 19 \\
\hline 3 & 3 & 3 & 0 & 0 \\
\hline 5 & 8 & 3 & 3 & -5 \\
\hline 13 & 25 & 18 & 12 & -7 \\
\hline 3 & 3 & 6 & 0 & 3 \\
\hline 0 & 1 & 1 & 1 & 0 \\
\hline 4 & 6 & 8 & 2 & 2 \\
\hline 14 & 14 & 13 & 0 & -1 \\
\hline 0 & 0 & 0 & 0 & 0 \\
\hline 2 & 2 & 2 & 0 & 0 \\
\hline
\end{tabular}

Note: Figures are number of first-time freshmen, graduating from high school in the last 12 months, who were residents of the District of Columbia, as reported in the IPEDS database. 


\section{Table 5. Differences in Application Behavior among Financial Aid Applicants \\ District of Columbia:}

\begin{tabular}{|c|c|c|c|}
\hline \multirow{3}{*}{$\begin{array}{l}\text { (Standard Errors in Parentheses) } \\
\text { P(Apply to a Public Coll in MD, VA) }\end{array}$} & 1998-99 & 2001-02 & Change: \\
\hline & 0.383 & 0.546 & 0.163 \\
\hline & & & (0.015) \\
\hline \multirow{2}{*}{ P(Apply to a Public Coll Outside DC) } & 0.547 & 0.665 & 0.118 \\
\hline & & & $(0.015)$ \\
\hline \multirow{2}{*}{ Number of Schools Listed on FAFSA } & 3.019 & 3.222 & 0.202 \\
\hline & & & $(0.062)$ \\
\hline \multirow{4}{*}{$\begin{array}{l}\text { S.D. Number of Schools Listed } \\
\text { N: }\end{array}$} & 2.089 & 2.063 & \\
\hline & 2,054 & 2,416 & \\
\hline & & Maryland: & \\
\hline & 1998-99 & 2001-02 & Change: \\
\hline \multirow[t]{2}{*}{$\mathrm{P}($ Apply to a Public Coll in MD, VA) } & 0.757 & 0.763 & 0.007 \\
\hline & & & $(0.004)$ \\
\hline \multirow[t]{2}{*}{ P(Apply to a Public Coll Outside DC) } & 0.818 & 0.825 & 0.007 \\
\hline & & & $(0.003)$ \\
\hline \multirow[t]{2}{*}{ Number of Schools Listed on FAFSA } & 2.600 & 2.745 & 0.145 \\
\hline & & & $(0.015)$ \\
\hline \multirow{3}{*}{$\begin{array}{l}\text { S.D. Number of Schools Listed } \\
\mathrm{N} \text { : }\end{array}$} & 1.840 & 1.877 & \\
\hline & 28,209 & $\begin{array}{r}31,381 \\
\text { Virginia: }\end{array}$ & \\
\hline & 1998-99 & 2001-02 & Change: \\
\hline \multirow[t]{2}{*}{$\mathrm{P}($ Apply to a Public Coll in MD, VA) } & 0.782 & 0.773 & -0.008 \\
\hline & & & $(0.003)$ \\
\hline \multirow[t]{2}{*}{ P(Apply to a Public Coll Outside DC) } & 0.832 & 0.826 & -0.006 \\
\hline & & & $(0.003)$ \\
\hline \multirow{2}{*}{ Number of Schools Listed on FAFSA } & 2.262 & 2.377 & 0.115 \\
\hline & & & $(0.013)$ \\
\hline \multirow{9}{*}{$\begin{array}{l}\text { S.D. Number of Schools Listed } \\
\mathrm{N} \text { : }\end{array}$} & 1.656 & 1.725 & \\
\hline & 34,663 & 36,260 & \\
\hline & Differen & DC versu & MD,VA: \\
\hline & 1998-99 & $\underline{2001-02}$ & Change \\
\hline & -0.387 & -0.223 & 0.1641 \\
\hline & & & 0.0000 \\
\hline & -0.279 & -0.160 & 0.1182 \\
\hline & & & 0.0000 \\
\hline & 0.606 & $0.6 / 4$ & $\begin{array}{r}0.0136 \\
0.0000\end{array}$ \\
\hline
\end{tabular}


Table 6. Changes in the Probability of Applying to a Public College

in MD and VA: 1998-99 to 2001-02

DC

Year 1998

Year 2000

Year 2001

DC*Year 1998

DC*Year 2000

DC* Year 2001

Other Covariates?

Observations

\begin{tabular}{|c|c|c|c|c|c|c|}
\hline \multirow[b]{2}{*}{ Total } & \multirow[b]{2}{*}{$\begin{array}{c}\text { Add } \\
\text { Controls }\end{array}$} & \multicolumn{5}{|c|}{ Estimated Separately for Selected Subsamples: } \\
\hline & & $\begin{array}{c}\text { Parents No } \\
\text { College }\end{array}$ & $\begin{array}{c}\text { Parent w/ } \\
\text { Some } \\
\text { College }\end{array}$ & $\begin{array}{c}\text { Family } \\
\text { Income } \\
<75 \mathrm{k}\end{array}$ & $\begin{array}{c}\text { Family } \\
\text { Income } \\
>=75 \mathrm{k}\end{array}$ & Zero EFC \\
\hline \multicolumn{7}{|c|}{$\mathrm{P}$ (Apply to a Public College in Maryland or Virginia) } \\
\hline-0.3764 & -0.3854 & -0.3685 & -0.4082 & -0.3718 & -0.4506 & -0.3945 \\
\hline$(0.0109)$ & $(0.0109)$ & $(0.0144)$ & $(0.0166)$ & $(0.0121)$ & $(0.0242)$ & $(0.0193)$ \\
\hline-0.0154 & -0.0234 & -0.0285 & -0.0155 & -0.0172 & -0.0283 & -0.0237 \\
\hline$(0.0027)$ & $(0.0027)$ & $(0.0044)$ & $(0.0034)$ & $(0.0031)$ & $(0.0053)$ & $(0.0073)$ \\
\hline-0.0120 & -0.0089 & -0.0238 & 0.0011 & -0.0140 & 0.0007 & -0.0202 \\
\hline$(0.0026)$ & $(0.0026)$ & $(0.0041)$ & $(0.0034)$ & $(0.0031)$ & $(0.0048)$ & $(0.0067)$ \\
\hline-0.0018 & 0.0046 & 0.0005 & 0.0053 & 0.0054 & -0.0005 & 0.0088 \\
\hline$(0.0026)$ & $(0.0026)$ & $(0.0040)$ & $(0.0034)$ & $(0.0031)$ & $(0.0047)$ & $(0.0067)$ \\
\hline 0.0225 & 0.0253 & 0.0261 & 0.0302 & 0.0133 & 0.0856 & -0.0033 \\
\hline$(0.0140)$ & $(0.0139)$ & $(0.0184)$ & $(0.0210)$ & $(0.0147)$ & $(0.0379)$ & $(0.0246)$ \\
\hline 0.0995 & 0.0986 & 0.0872 & 0.1193 & 0.0853 & 0.1765 & 0.0600 \\
\hline$(0.0111)$ & $(0.0111)$ & $(0.0145)$ & $(0.0165)$ & $(0.0116)$ & $(0.0272)$ & $(0.0197)$ \\
\hline 0.1362 & 0.1332 & 0.1375 & 0.1194 & 0.1184 & 0.1849 & 0.1129 \\
\hline$(0.0095)$ & $(0.0096)$ & $(0.0117)$ & $(0.0164)$ & $(0.0101)$ & $(0.0258)$ & $(0.0161)$ \\
\hline
\end{tabular}

Note: The coefficients on the $\mathrm{DC}^{*}$ year interactions measure the change in the probability of applying to a public college in Maryland or Virginia for DC residents relative to the change for MD, VA residents. (The baseline year was 1999.) The sample consisted of all financial aid applicants from DC, MD and VA during the 1998-99 through 2001-02, in which both the student and the parent listed the same state as their permanent legal address. The above represent marginal effects on probabilities evaluated at the mean characteristics of the sample or subsample, based on probit specifications. Other covariates included dummy variables for mother's education, father's education, four income categories, four asset categories, a zero EFC indicator and a zero asset indicator. 


\section{Table 7. Changes in the Probability of Attending Various Types of Colleges for DC, MD and VA Pell Grant Recipients 1998-2001}

\begin{tabular}{|c|c|c|c|c|c|c|c|c|}
\hline & $\begin{array}{l}\text { Public } \\
\text { MD,VA }\end{array}$ & $\begin{array}{c}\text { Public } \\
\text { Outside } \\
\text { MD,VA, } \\
\text { DC }\end{array}$ & $\begin{array}{c}\text { Private } \\
\text { College } \\
\text { in } \\
\text { DC Area }\end{array}$ & $\begin{array}{c}\text { Private } \\
\text { HBCU in } \\
\text { DC, } \\
\text { MD,VA }\end{array}$ & $\begin{array}{c}\text { Private } \\
\text { HBCU } \\
\text { Outside } \\
\text { MD,VA, } \\
\text { DC }\end{array}$ & $\begin{array}{c}\text { Private } \\
\text { non- } \\
\text { HBCU } \\
\text { Outside } \\
\text { MD,VA, } \\
\text { DC }\end{array}$ & $\begin{array}{c}\text { For- } \\
\text { Profit } \\
\text { Proprie- } \\
\text { tary } \\
\text { School }\end{array}$ & UDC \\
\hline \multirow[t]{2}{*}{ DC } & -0.525 & 0.070 & 0.072 & 0.021 & 0.056 & 0.079 & 0.062 & 0.0916 \\
\hline & $(0.013)$ & $(0.011)$ & $(0.010)$ & $(0.006)$ & $(0.008)$ & $(0.014)$ & (0.011) & $(0.0183)$ \\
\hline \multirow[t]{2}{*}{ Year 1998} & 0.009 & -0.005 & 0.000 & -0.004 & -0.002 & -0.006 & 0.006 & -0.0002 \\
\hline & $(0.005)$ & $(0.002)$ & $(0.0$ & (0.001) & $(0.001)$ & $(0.003)$ & $(0.003)$ & $(0.0002)$ \\
\hline \multirow[t]{2}{*}{ Year 2000} & 0.010 & 0.001 & 0.000 & -0.003 & -0.003 & -0.007 & 0.001 & -0.0001 \\
\hline & $(0.0$ & $(0$ & (0. & (0. & 1) & $(0.003)$ & $(0.0$ & 02) \\
\hline \multirow[t]{2}{*}{ Year 2001} & 0.025 & 0.004 & -0.002 & 0.004 & 0.000 & -0.014 & -0.013 & 0.0001 \\
\hline & $(0.0$ & $(0.003)$ & $(0.0$ & $(0.1$ & $(0.001)$ & $(0.003)$ & $(0.003)$ & $(0.0002)$ \\
\hline \multirow[t]{2}{*}{ DC*Year 1998} & 0.019 & 0.004 & 0.000 & 0.011 & -0.001 & 0.000 & -0.022 & 0.0005 \\
\hline & $(0.027)$ & $(0.010)$ & $(0.002)$ & $(0.007)$ & $(0.002)$ & $(0.014)$ & (0.009) & $(0.0005)$ \\
\hline \multirow[t]{2}{*}{ DC*Year 2000} & 0.169 & -0.020 & -0.002 & 0.003 & -0.004 & -0.039 & -0.015 & 0.0001 \\
\hline & $(0.018)$ & $(0.007)$ & $(0.002)$ & $(0.005)$ & $(0.002)$ & $(0.011)$ & $(0.010)$ & $(0.0003)$ \\
\hline \multirow[t]{2}{*}{ DC* Year 2001} & 0.160 & 0.008 & -0.002 & -0.002 & -0.002 & -0.054 & -0.041 & 0.0001 \\
\hline & $(0.018)$ & $(0.010)$ & $(0.002)$ & $(0.004)$ & $(0.002)$ & $(0.009)$ & $(0.007)$ & $(0.0003)$ \\
\hline Dbservations & 74734 & 74734 & 74734 & 74734 & 74734 & 74734 & 74734 & 74734 \\
\hline
\end{tabular}

Note: The coefficients on $\mathrm{DC}^{*}$ year interactions measure the change in probability of attendance for DC residents relative to the change for MD and VA residents. (The baseline year was 1999.) To ensure comparability as the Pell Grant maxima increased, the sample was limited to Pell Grant recipients with an EFC < 2600 from DC, MD and VA during the 1998-99 through 2001-02 award cycles. The above represent marginal effects on probabilities evaluated at the mean characteristics of the sample or subsample, based on probit specifications. Other covariates included dummy variables for mother's education, father's education, four income categories, four asset categories, a zero EFC indicator and a zero asset indicator. 


\section{Table 8. Ratio of DC TAG Recipients to the Number of Own Children 15- 17 Yrs Old by Median HH Income in Block Group}

\begin{tabular}{|c|c|c|c|c|}
\hline & $\begin{array}{l}\text { Median } \\
\text { Household }\end{array}$ & \multicolumn{3}{|c|}{ Recipiency Ratio: } \\
\hline Decile & Income & $\underline{2000}$ & 2001 & $\underline{2002}$ \\
\hline Lowest & $\$ 12,672$ & 0.037 & 0.043 & 0.057 \\
\hline 2nd & 20,385 & 0.084 & 0.070 & 0.049 \\
\hline $3 r d$ & 24,087 & 0.086 & 0.081 & 0.082 \\
\hline 4th & 27,584 & 0.094 & 0.070 & 0.088 \\
\hline 5th & 31,194 & 0.125 & 0.101 & 0.099 \\
\hline 6th & 34,102 & 0.123 & 0.088 & 0.093 \\
\hline 7th & 38,591 & 0.144 & 0.114 & 0.115 \\
\hline 8th & 47,163 & 0.149 & 0.106 & 0.102 \\
\hline 9th & 60,682 & 0.202 & 0.153 & 0.129 \\
\hline Highest & 114,390 & 0.140 & 0.115 & 0.117 \\
\hline Total & $\$ 39,737$ & 0.115 & 0.092 & 0.091 \\
\hline
\end{tabular}

Note: The recipiency ratio is defined as the ratio of the number of new DC TAG recipients in that block group to the number of own and related children between the ages of 15 and 17 . Twentyeight block groups with more than 50 people living in college dormitories were dropped. There were 398 block groups remaining. Income deciles were calculated using median household income in the block group and weighting by the number of own children between the ages of 15 and 17. 


\section{Table 9. New Recipients by Type of High School Attended (2002-03)}

DC Public

DC Charter

Public Outside DC

Catholic Private

Non-Catholic Private

Federal Correctional

\section{$\%$ of New Recipients}

73

4

5

10

7

0

Note: Based on author's categorization of high school names reported by first-time recipients in 2002-03. The 23 percent of recipients that did not report any high school were excluded. 
Appendix Table 1. Mean Tuition Less Total Grant Aid

Type of Institution:

\begin{tabular}{crrrr} 
& 4-year & 2-year & $<2$-year & \multicolumn{1}{l}{ Total } \\
Total & $\$ 3,618$ & $\$ 716$ & $\$ 3,544$ & $\$ 2,235$
\end{tabular}

Student's state of legal residence

$\begin{array}{lcccr}\text { Alabama } & \$ 2,190 & \$ 302 & \mathrm{n} / \mathrm{a} & \$ 1,354 \\ \text { Alaska } & \$ 1,952 & \text { low } \mathrm{n} & \mathrm{n} / \mathrm{a} & \$ 1,984 \\ \text { Arizona } & \$ 2,418 & \$ 470 & \mathrm{n} / \mathrm{a} & \$ 989 \\ \text { Arkansas } & \$ 1,771 & \$ 276 & \$ 792 & \$ 1,063 \\ \text { California } & \$ 3,733 & \$ 389 & \$ 4,373 & \$ 1,516 \\ \text { Colorado } & \$ 2,579 & \$ 812 & \$ 1,381 & \$ 1,695 \\ \text { Connecticut } & \$ 7,167 & \$ 925 & \$ 6,562 & \$ 3,906 \\ \text { Delaware } & \$ 4,768 & \$ 684 & \mathrm{n} / \mathrm{a} & \$ 2,487 \\ \text { District of Columbia } & \$ 7,049 & \mathrm{n} / \mathrm{a} & \mathrm{n} / \mathrm{a} & \$ 6,272 \\ \text { Florida } & \$ 2,721 & \$ 857 & \$ 2,379 & \$ 1,627 \\ \text { Georgia } & \$ 2,008 & \$ 331 & \mathrm{n} / \mathrm{a} & \$ 1,189 \\ \text { Hawaii } & \$ 2,058 & \mathrm{n} / \mathrm{a} & \$ 3,341 & \$ 2,133 \\ \text { Idaho } & \$ 1,735 & \$ 837 & \mathrm{n} / \mathrm{a} & \$ 1,244 \\ \text { Illinois } & \$ 4,422 & \$ 571 & \$ 4,997 & \$ 2,268 \\ \text { Indiana } & \$ 2,350 & \$ 1,063 & \mathrm{n} / \mathrm{a} & \$ 2,076 \\ \text { lowa } & \$ 3,275 & \$ 1,231 & \mathrm{n} / \mathrm{a} & \$ 2,856 \\ \text { Kansas } & \$ 1,966 & \$ 584 & \$ 7,353 & \$ 1,772 \\ \text { Kentucky } & \$ 2,573 & \$ 1,815 & \$ 535 & \$ 2,273 \\ \text { Louisiana } & \$ 2,043 & \$ 395 & \$ 3,164 & \$ 1,554 \\ \text { Maine } & \$ 5,994 & \mathrm{n} / \mathrm{a} & \mathrm{n} / \mathrm{a} & \$ 5,994 \\ \text { Maryland } & \$ 5,616 & \$ 640 & \mathrm{n} / \mathrm{a} & \$ 3,207 \\ \text { Massachusetts } & \$ 6,931 & \$ 705 & \$ 3,699 & \$ 4,343 \\ \text { Michigan } & \$ 3,332 & \$ 685 & \$ 3,435 & \$ 2,066 \\ \text { Minnesota } & \$ 4,280 & \$ 1,153 & \mathrm{n} / \mathrm{a} & \$ 2,676 \\ \text { Mississippi } & \$ 1,811 & \$ 411 & \mathrm{n} / \mathrm{a} & \$ 1,083 \\ \text { Missouri } & \$ 3,061 & \$ 1,634 & \$ 8,394 & \$ 2,831 \\ \text { Montana } & \$ 1,982 & \mathrm{n} / \mathrm{a} & \mathrm{n} / \mathrm{a} & \$ 2,023 \\ \text { Nebraska } & \$ 3,016 & \$ 347 & \mathrm{n} / \mathrm{a} & \$ 1,593 \\ \text { Nevada } & \$ 3,793 & \$ 934 & \mathrm{n} / \mathrm{a} & \$ 1,854 \\ \text { New Hampshire } & \$ 4,808 & \mathrm{n} / \mathrm{a} & \mathrm{n} / \mathrm{a} & \$ 4,840 \\ \text { New Jersey } & \$ 6,895 & \$ 1,108 & \$ 2,576 & \$ 4,824 \\ \text { New Mexico } & \$ 1,607 & \$ 129 & \mathrm{n} / \mathrm{a} & \$ 916 \\ \text { New York } & \$ 5,235 & \$ 1,112 & \$ 2,817 & \$ 3,472 \\ \text { North Carolina } & \$ 2,423 & \$ 315 & \$ 5,882 & \$ 1,293 \\ \text { North Dakota } & \$ 3,255 & \$ 1,212 & \mathrm{n} / \mathrm{a} & \$ 2,075 \\ \text { Ohio } & \$ 3,815 & \$ 1,241 & \$ 1,739 & \$ 2,688 \\ \text { Oklahoma } & \$ 1,186 & \$ 468 & \$ 3,699 & \$ 901 \\ \text { Oregon } & \$ 4,320 & \$ 602 & \$ 6,762 & \$ 2,817 \\ \text { Pennsylvania } & \$ 5,349 & \$ 1,662 & \$ 4,300 & \$ 4,036 \\ \text { Rhode Island } & \$ 6,908 & \$ 811 & \$ 11,240 & \$ 3,040 \\ \text { South Carolina } & \$ 3,308 & \$ 448 & \mathrm{n} / \mathrm{a} & \$ 1,742 \\ \text { South Dakota } & \$ 3,398 & \mathrm{n} / \mathrm{a} & \mathrm{n} / \mathrm{a} & \$ 3,437 \\ \text { Tennessee } & \$ 2,232 & \$ 647 & \$ 2,104 & \$ 1,684 \\ \text { Texas } & \$ 2,339 & \$ 526 & \$ 3,502 & \$ 1,476 \\ \text { Utah } & \$ 6,974 & \text { low } \mathrm{n} & \text { low n } & \$ 6,932 \\ \text { Vermont } & & & & \end{array}$




$\begin{array}{llllr}\text { Virginia } & \$ 3,947 & \$ 1,088 & \$ 3,866 & \$ 2,367 \\ \text { Washington } & \$ 3,549 & \$ 1,131 & \$ 6,926 & \$ 2,258 \\ \text { West Virginia } & \$ 1,353 & \$ 1,859 & \$ 2,042 & \$ 1,432 \\ \text { Wisconsin } & \$ 3,467 & \$ 914 & \text { low } \mathrm{n} & \$ 2,432 \\ \text { Wyoming } & \$ 2,047 & \$ 526 & \text { low } \mathrm{n} & \$ 981\end{array}$

